\title{
Country report for Zambia
}

Pamela Towela Sambo (lead author), Andrew Nkunika (contributing author) \& Nelly Zulu (contributing author)

\section{Introduction}

The purpose of this report is to evaluate the provisions of relevant laws and policies in Zambia in order to ascertain whether sustainable soil management is being implemented in the country. This is against the background that the Intergovernmental Panel on Climate Change (IPCC), has recently published a report which re-affirms that effective land management, among other measures, can contribute to tackling climate change. ${ }^{1}$ The IPCC is the world's leading body in assessing the state of scientific knowledge related to climate change, its impacts, potential future risks, and possible response options.

Sustainable soil management is important for Zambia and other countries because it is one definite pathway to achieving some of the Sustainable Development Goals (SDGs). ${ }^{2}$ The relevant SDGs include: ending all forms of poverty and hunger; achieving food security through improved nutrition; promoting sustainable agriculture; and taking urgent action to combat climate change and its impacts. ${ }^{3}$

This report is divided into main sections which provide insight into government structure which deal with the way Zambia is set up for governance through three organs, the Executive, Legislature and Judicature; as well as the main drivers of soil degradation and the applicable laws and policies to safeguard the soil.

\subsection{Geographic and climatic information}

The Republic of Zambia is a landlocked country in Southern Africa covering a surface area of $752,972 \mathrm{~km}^{2}$ located roughly between latitudes $8^{\circ}$ and $18^{\circ}$ south of the equator. ${ }^{4}$ The country is surrounded by the Democratic Republic of Congo, Tanzania, Malawi, Mozambique, Zimbabwe, Botswana, Namibia and Angola.

1 IPCC (2019: 2)

2 The sustainable development goals (SDGs) are discussed more substantively below.

3 See https://bit.ly/3cRsOYw, accessed 3 February 2021.

4 Japan Association for International Collaboration of Agriculture and Forestry (2008). 
Generally, there are three seasons in Zambia, a summer rainy season (November to April); a cool, dry winter season (May to August); and a hot dry season (September and October).

Zambia is located in the tropical climatic zone, approximately 900-1,500 metres above sea level, excluding the basins of the Zambezi, Luangwa and Kafue rivers, and the areas around Lakes Tanganyika, Mweru and Bangweulu, which are relatively cool. ${ }^{5}$ The country's geographical position and high altitude provides it with sub-tropical vegetation and climatic conditions.

The season with the highest temperature is the month of October. The rainy season extends from November/December to around April, and the dry season from around May to around November. The average annual rainfall amounts to around 1,000 mm but varies by region. The rainfall in the south and south-west regions is around 900 $\mathrm{mm}$, but in the north and north-west regions it exceeds 1,400 $\mathrm{mm}$. After the cool season from May to mid-August, the temperatures start rising. In the capital, Lusaka, the minimum and maximum average temperatures in July are 9 degrees Celsius and 23 degrees Celsius respectively; and in January 17 degrees Celsius and 26 degrees Celsius respectively. Normally, the annual average rainfall per annum is about $810 \mathrm{~mm} .^{6}$

As with the rest of Africa, and particularly the sub-Saharan region, Zambia has been experiencing the effects of climate change resulting in extreme weather conditions, such as droughts, rising temperatures and unpredictable rainfall patterns. ${ }^{7}$ The frequency and intensity of climate events is expected to rise in future, with negative impacts on the economy and consequently people's livelihoods. ${ }^{8}$

\subsection{Historical background, demographic information and level of education}

Zambia attained its political independence from Britain in 1964. The country's political history spans the era of multiparty democracy from 1964 to 1972; one-party rule thereafter until 1990; and a multiparty democracy system of governance from 1991 to date. ${ }^{9}$ Administratively, the country is divided into 10 provinces, namely Central, Copperbelt, Eastern, Luapula, Lusaka, Muchinga, Northern, North-Western, Southern and Western. These provinces are further subdivided into districts, constituencies and wards. ${ }^{10}$

$5 \quad$ Plisnier et al. (2018).

6 Resilience and Economic Inclusion Team (2016).

7 Ministry of National Development Planning (2016: 2-3).

$8 \quad$ Plisnier et al. (2018); Sintayehu (2018: 225-227); Ministry of National Development Planning (2016: 4).

9 Phiri (2006: 1-5).

10 Central Statistical Office (2015: 1). 
It has been noted that after political independence in the 1960s, Zambia enjoyed a strategic role as supporter of the liberation movements in Southern Africa. Zambia gradually lost its strategic importance over the years following the deterioration of African economies, the demise of the Soviet Union and the fragmentation of the 'Third World' as countries in South-East Asia grew rapidly and drew away. Zambia has also had enduring relationships with China and India since its independence. ${ }^{11}$ These relationships resulted in a number of projects to support the Zambian economy. The Tanzania-Zambia (TAZARA) railway, for example, was the first and probably bestknown example of China's engagement in Africa. ${ }^{12}$ In trade terms, Zambia's loss of strategic importance has resulted in negative consequences for the country's negotiating power in both traditional and non-traditional development assistance.

According to the Population and Demographic Projections for 2011-2035 Report (Projections Report), Zambia's population was estimated to stand at 15.9 million in 2016, out of which 7.9 million would be males and 8.0 million females. ${ }^{13}$ Also, 9.2 million would reside in rural areas and 6.7 million in urban areas. The population is expected to continue growing at an average annual rate of around $2.8 \%$ during the projection period 2011-2035. ${ }^{14}$ The population in rural areas is expected to grow at a relatively stable average rate of $2.4 \%$ per annum, while the urban population is expected to grow at $3.5 \%$ per annum during the same period.

At provincial level, Lusaka has the largest population with 2,888,575 persons, while the North-Western Province has the smallest population with 856,286 persons. The population was expected to grow to 17.9 million by 2020 of which 10.1 million would reside in rural areas, while 7.8 million would reside in urban areas. ${ }^{15}$ During the projection years, the age structure was expected to remain relatively unchanged although the proportion of children in the population would fall. The young population was expected to result in growth in the reproductive age group (15-49) and the economically active age group (15-64). ${ }^{16}$

The Projections Report further stated that in 2016 the estimated or average life expectancy at birth would be 53.7 years. Females had a higher life expectancy at birth of 56.1 years compared to 51.5 years for males. The projected decline in fertility and mortality was expected to lead to an increase in life expectancy at birth and at different ages, as well as an increase in the proportion of the elderly of 65 years and older, in the long run. ${ }^{17}$

11 Prizzon (2013: iv).

12 Monson (2013: 52).

13 See https://bit.ly/3tsja4H, accessed 3 February 2021.

14 Ibid.

15 See https://bit.ly/2YHQ1En, accessed 3 February 2021.

16 Ministry of Finance (2017: 31).

17 Ibid.: 33. 
The country's average population density is 20.6 persons per $\mathrm{km}^{2}$, while Lusaka Province has the highest density of 126.8 persons per $\mathrm{km}^{2}$. There are 73 ethnic groups in Zambia with seven major languages used besides English, which is the official language. The seven major languages are Bemba, Kaonde, Lozi, Lunda, Luvale, Nyanja and Tonga. ${ }^{18}$

Zambia's Vision 2030, the long-term national development plan, provides a strategic focus for the country to become "a prosperous middle-income nation." 19 In order to attain this vision, the role of quality education is critical. In 2015, the Ministry of Education, Science, Vocational Training and Early Education was split into two distinct parts - the Ministry of Higher Education and the Ministry of General Education. The Education System consists of early childhood education (ECE), primary, and secondary under the Ministry of General Education. ECE (pre-school) provides education for children aged 3-6 years, while primary level runs from grades 1 to 7 (7-13 years old) and the secondary level runs from grades 8 to 12 (14-18 years old). The professional or tertiary levels include universities and colleges and fall under the jurisdiction of the Ministry of Higher Education. ${ }^{20}$

The adult literacy in Zambia currently stands at $68 \%{ }^{21}$ and can be related to the generally low awareness levels about the environment, let alone its constituent elements like soil. The priority areas for the general education subsector have been access and participation, quality and relevance of education and equity. The targets by the end of the Revised Sixth National Development Plan period were to attain net enrolment ratio (NER) of $100 \%$. With regard to the transition rate, the targets for 2016 were $68 \%$ at Grade 7 and $50 \%$ at Grade $9 .{ }^{22}$ These targets were to be achieved through the construction of new schools and additional classrooms in existing schools in order to enhance access. Significant investment was made in strategies to promote equity in access to education during the period of the Fifth and Sixth National Development Plans.

According to the Ministry of General Education, the Early Childhood Education (ECE) level made notable achievements with the shifting of the mandate of providing ECE from the Ministry of Local Government and Housing to the Ministry of Education. The proportion of learners with ECE experience rose from $20.3 \%$ in 2005 to $24.4 \%$ in $2015 .{ }^{23}$

There is, however, much more that needs to be done to enhance access to ECE, in order to meet the target of $30 \%$ of new Grade 1 entrants with ECE experience. Overall, the education sector benefits an average of about $15-17 \%$ of the national budget or

18 Central Statistical Office, (2013: 1).

19 Ministry of National Development Planning (2006: 1-2).

20 Ministry of General Education (2017).

21 Ibid.; Fadjukoff (2015: 127).

22 Ministry of Finance (2011: 41).

23 Ministry of General Education (2017). 
about $2-4 \%$ of the GDP - lower than the SADC recommended minimum threshold of $20 \%$ of national budget or $6 \%$ of GDP. ${ }^{24}$

\subsection{Main economic activities}

This section discusses the main economic activities in Zambia, and their impact on the general environmental well-being and, more specifically, sustainable soil management. The highest environmental impact stems from mining, while the tourism sector complements environmental sustainability because it is premised on preserving biological diversity, such as wildlife and the floral kingdom, among others.

\subsubsection{Mining}

Zambia is the seventh largest copper producer globally, ${ }^{25}$ and mining contributes over $75 \%$ of the country's total export value. It has been observed that the total contribution of mining to gross domestic product (GDP) averaged at 12.9\% for the period 20062015 and that the sector created 56,227 jobs in 2005 , which increased to 82,725 in $2014 .^{26}$ In recognition of the important national economic role that mining continues to play, such as employment creation, revenue generation and rural-urban development, Zambia continues to make efforts to reduce copper dependence and support the diversification to other minerals, such as gemstones and other industrial minerals. Although minerals such as cobalt, coal, emeralds and gold are mined in Zambia, their contribution to the country's total export value is not clear. Generally, the mineral output in the sector has been lower than it was historically. For example, the 2015 copper output of 710,560 metric tonnes was below government's projection of 800,000 metric tonnes. $^{27}$

\subsubsection{Agriculture}

Owing to the falling prices of copper on the global market, Zambia has embarked on a programme to diversify its economy in order to reduce overdependence on copper. Copper- price fluctuations have presented a risk and have led to a sharp decline in

24 OSISA (2015: 10-18).

25 Major countries in copper mine production worldwide from 2010 to 2018, see https://www.statista.com/statistics/264626/copper-production-by-country/, accessed 12 April 2019.

26 Mining Partnerships for Development (2014: 11).

27 Ministry of National Development Planning (2017: 26). 
revenue from export over the years. This economic meltdown also happened in Zambia during the Fifth National Development Plan (FNDP) period between 2007 and 2009, when copper prices fell by $28 \%$. This in turn led to a corresponding foreign direct investment (FDI) fall of $47 \%$. The FDI flows into Zambia remained highly concentrated in the copper mining sector. The agriculture, manufacturing and tourism sectors, which create and sustain productive employment, received only negligible investments. ${ }^{28}$

About 58\% of Zambia's total land area of 75 million hectares is potentially good for agricultural production, although most of this arable land is yet to be fully utilised for the purpose of increasing the contribution of the agricultural sector to the national economy. Zambia's agricultural activities are mainly rain-fed despite having large water bodies that can easily be tapped for irrigation purposes. ${ }^{29}$ Against this, it has widely been observed that Zambia has the potential to increase its agricultural output. ${ }^{30}$ While arable land is plentiful in the country, only about $15 \%$ of it is under cultivation. In recent years, the promotion of the agricultural sector has been one of government's top priorities in a bid to diversify the economy and reduce overreliance on its traditional products and exports, such as copper and cobalt. The total contribution of agriculture to GDP averaged at $9.8 \%$ in the period 2006 to $2015 .{ }^{31}$ With a combination of arable land and an annual rainfall ranging from 800 to $1,400 \mathrm{~mm}^{32}$, the country has mediumto high-potential for agriculture; yet maintains a high underutilised acreage. In the unused arable land area, however, a reduction of forest area could lead to destruction of the natural environment, thus the extent of this transformation to farmland should be carefully examined. ${ }^{33}$

The Zambian agricultural sector comprises crops, livestock, and fisheries. ${ }^{34}$ There are three broad categories of farmers: small-scale, medium, and large-scale. Smallscale farmers are generally subsistence producers of staple foods such as maize, sorghum, millet, and cassava, with occasional marketable surplus. Most Zambians are subsistence farmers. Medium-scale farmers produce maize and a few other cash crops such as cotton, groundnuts, sorghum, rice, sunflower seeds, coffee, sugar and fruits. Large-scale farmers produce various crops such as sugar, soybeans, coffee, groundnuts, rice, tobacco, paprika, wheat and cotton, as well as horticultural produce. A small percentage of produce from large-scale farmers is sold on the local markets while the bulk of the high-grade produce is reserved for export. ${ }^{35}$ While the country enjoys $40 \%$ 
of sub-Saharan water resources, there is very little mechanical irrigation and most farms are dependent on rain-fed growing cycles. ${ }^{36}$ This presents insurmountable challenges when the rain patterns fluctuate, as has been seen in recent times owing to the effects of climate change.

For instance, during the period 2006-2015, output for 13 of the 18 major crops declined largely as a result of erratic rainfall, which in recent times has negatively affected the yield rates. For example, in the 2015-2016 farming season, maize production decreased by $21.9 \%$ from 3,350,671 to 2,618,221 metric tonnes (MT). Such a drastic decline has the potential to affect the rural economy in the country, because most of the agricultural activities are undertaken in these areas. Further, with the high employment opportunities offered by the agricultural sector, it is likely that such dramatic declines in production could further spur the rural-urban drift in Zambia. At the heart of addressing these challenges, there are multi-pronged efforts at mitigating the effects of climate change across all sectors. ${ }^{37}$

\subsubsection{Manufacturing}

The manufacturing sector accounted for about $7.8 \%$ of the country's GDP and an average annual growth rate of 3\% from 2006 to 2015. The 2005 and 2014 Labour Force Surveys showed that there were 166,143 persons employed in the manufacturing sector in 2005, which increased to 223,681 in 2014. The manufacturing sector was pivotal in economic development as it played a key role in the backward and forward linkages to economic growth. It has been further noted that in the latter years of the Sixth National Development Plan (SNDP) 2011-2015, there was slow growth in the manufacturing sector owing to some of the constraints to growth such as the energy deficit and high production costs which contributed to a drop of output of between $60 \%$ and $70 \%{ }^{38}$

The sector is largely driven by the agro-processing (food and beverages), textile, and leather subsectors. There is also secondary processing of metals, smelting and refining of copper, which have led to the manufacturing of metal products. The sector also benefits from the emerald mining industry and manufactures a number of ornaments for export purposes. Fertilizers, chemicals, explosives and construction materials such as cement are also produced. Other activities include producing wood and paper products, vehicle parts and assembly, refining petroleum and light engineering. ${ }^{39}$

36 See http://www.fao.org/3/t0800e/t0800e0a.htm, accessed 2 February 2021.

37 Ministry of Finance (2017: 25).

38 Energy Regulation Board (2017: 1).

39 BoZ (2017a: 5). 


\subsubsection{Energy}

The country's demand for electricity stood at 1,949 megawatts (MW) in 2015, while the sector was only able to produce 1,281 MW, thus giving a deficit of $668 \mathrm{MW} .{ }^{40}$ This situation resulted from limited investment over the years, which was also compounded by non-cost-reflective tariffs. Further, the deficit was worsened by the effects of climate change on the availability of water, since Zambia's electricity generation is predominantly through hydropower. ${ }^{41}$ The current projections indicate that growth in demand will increase by $150 \mathrm{MW}$ to $200 \mathrm{MW}$ per annum. The peak demand for electricity in the country was projected at 3,000 MW by $2020 .{ }^{42}$ The increase in energy demand in Zambia is the result of the improved economic outlook.

The leading sectors in relation to electricity consumption were mining, construction, agriculture and services. Side by side with the expansion of the domestic economy, the national electricity consumption increased from 10,857.54 GWh in 2016 to $12,191.86$ GWh in 2017, thus reflecting $12.3 \%$ growth. ${ }^{43}$ Of this 2017 consumption, the mining sector accounted for $6,202.0 \mathrm{GWh}$ of total consumption representing $50.9 \%$ of the total electricity output. ${ }^{44}$ The demand for energy has steadily been rising with the increase in population and urbanisation, and the growth of industry and resultant energy needs.

In 2016, the country had installed energy capacity of 2,493 MW with hydro generation accounting for $97 \%$, while other sources were at $3 \%$. It was envisaged that other sources of energy, which include geothermal, wind, solar and coal, would grow to about $15 \%$ by $2030 .{ }^{45}$ To increase supply, there was a need for additional investment in hydro, geothermal, wind and solar energy generation. ${ }^{46}$ This would have a further bearing on the fuel used for domestic purposes, especially in rural areas where the absence of electricity forces people to use charcoal as a source of fuel. The increased generational capacity of electricity, coupled with the increase in rural electrification, means that there will be a decreased use of fossil fuels, resulting in reduction in deforestation and emission of greenhouse gases, as well as the reduction of soil erosion. It has been noted for example that in 2017, the Rural Electrification Authority (REA) continued to implement rural electrification projects nationally and had successfully completed 14 rural electrification projects, 11 being grid extensions and three solar projects. ${ }^{47}$ Energy generation in Zambia is not without impact on soil sustainability and the environment generally. For example, persistent organic pollutants (POPs),

40 Ministry of Finance (2017: 27).

41 Ministry of National Development Planning (2016: 7).

42 Ministry of Energy (2008: 3).

43 Energy Regulation Board (2017: 1-3).

44 ZDA (2017: 1).

45 Ministry of Energy (2008: 3-8).

46 Ministry of Finance (2017: 26).

47 Ibid. 
which are chemicals that have toxic properties and do not easily decompose in the environment are used as coolants and lubricants in electricity generation equipment such as transformers, capacitors and switches. They may include polychlorinated biphenyls (PCBs). These materials accumulate in the soil and organisms by ingestion through the food chain, thereby posing a hazard for human beings and animals. ${ }^{48}$

Further, according to ZEMA, as of 2016, Zambia had 16,000 transformers owned by electrical and mining companies of which 326 were identified as potentially containing PCBs. Some capacitors and oil circuit breakers were believed to contain PCBs. Furthermore, about 196 tonnes of PCB-contaminated soil was stored at the Kariba North Bank PCB storage facility, while some other PCB-contaminated oil, polythene sheets and personal protective equipment (PPE), and transformer shells were found. Of greatest concern to this discussion is that, at present, Zambia has no capacity for disposal of PCB materials. ${ }^{49}$ This is an immensely worrisome situation for soil sustainability and general environmental well-being.

In addition, the fall in the country's hydropower generation in recent years by about $600 \mathrm{MW}$, mainly attributed to poor rainfall patterns, has hampered the country's economic growth prospects in agriculture, manufacturing, mining and other services. Other adverse effects have led to increased costs of treating climate-related diseases such as malaria, the loss of natural environments, damage to infrastructure and disruption of biodiversity. ${ }^{50}$ Climate change adaptation and mitigation will, therefore, promote social well-being, including better health, growth of the economy and at the same time reduce environmental risks, such as shortage of water, air pollution and other effects. $^{51}$

\subsubsection{Construction}

The construction industry continues to play an integral part in the development of the economy and is one of the important catalysts for growth. Activities in the subsector are driven by public and private projects, such as roads, stadiums, hospitals, schools, and residential and commercial property. As noted in the section on mining, the construction industry has fuelled illegal quarrying, which in turn has severe impacts on soil sustainability. The construction industry continued to grow over the past 12 years at a steady annual average rate of $17.5 \%$. This growth can be directly attributed to increased public and private sector investment on infrastructure development. ${ }^{52}$ With

\footnotetext{
48 ZEMA (2017: 113).

49 Ibid.

50 Sintayehu (2018: 225-227).

51 Ministry of National Development Planning (2016: 7).

52 ZDA (2017).
} 
inadequate safeguards, the growth of the construction sector is projected to cause further strain on soil sustainability.

\subsubsection{Tourism}

Government has identified tourism as an area of priority. ${ }^{53}$ Zambia's total annual international tourist arrivals increased from 668,862 in 2005 to 931,782 in 2015, representing a $39 \%$ increment. Tourism's average GDP contribution over the 5-year period from 2010 to 2014 was around $1.76 \%$ per annum. With regard to accommodation establishments, the sector recorded an increase of $25.6 \%$ from 933 in 2012 to 1,172 in 2015, with a corresponding $45.6 \%$ increase in bed spaces from 51,662 in 2012 to 75,253 in $2015 .{ }^{54}$ The increase was attributed to high demand for tourism enterprise businesses, mostly by local citizens. The room occupancy rate improved from 54.9\% in 2012 to $68.9 \%$ in 2015 owing to increased tourist arrivals. ${ }^{55}$

Despite these positive strides in the tourism sector, Zambia has continued to face stiff competition from other African countries in attracting tourists. For instance, in 2013, a total of 55.8 million arrivals were recorded in Africa, out of which Zambia only recorded 914,576 , representing $1.63 \%$. The number of foreign visitors to the country rose from 814,140 in 2010 to 914,576 in 2013 . From these arrivals, the country recorded annual direct earnings of US $\$ 441,062,536(\mathrm{~K} 2,271,472,063)$ in 2012 , which rose to US $\$ 540,209,718(\mathrm{~K} 2,971,153,451)$ in 2013 . The number of jobs in the sector rose from 44,292 in 2012 to 57,337 in 2013 . The top holiday markers for tourism to Zambia were Africans, accounting for $79 \%$ of the 914,576 visitors in 2013. ${ }^{56}$

During the Sixth National Development Plan period (2011-2015), a marginal increase in the average length of stay for tourists was recorded - from 5 days in 2012 to 6 days in 2013. This was attributed to inadequate diversification of tourism products, underdeveloped tourism circuits and tour packages, among others. ${ }^{57}$

\subsection{Gross national product}

It has been noted that Zambia's economy during the period 2000-2005 grew at an annual average of about $5.8 \%$, while the 2006-2015 period saw an upward and sustained growth averaging $6.9 \%$.

53 Ministry of Finance (2017: 27-28).

54 Ibid.

55 Ministry of Tourism (2016: 12-17).

56 Ministry of Finance (2017: 28).

57 Ibid.: 35 . 
Zambia's gross domestic product in December 2017 was US\$25.81 billion. The economy is predominantly driven by the agricultural and mining industries. The largest proportion of Zambia's exports go to Non-European Union Organisation for Economic Co-operation and Development (Non-EU OECD) countries, like Switzerland, followed by Asia (China), Southern African Development Community (SADC) and Common Market for Eastern and Southern Africa (COMESA) countries, while Switzerland and China are the main consumers of copper. ${ }^{58}$

The forestry industry contributes at least $3.7 \%$ to the GDP. Within this industry, the largest part is wood fuel, including commercial charcoal production of $2.2 \%$ and subsistence wood collection of $0.8 \%$, with about $90 \%$ of the people using the fuelwood thus produced. The productivity of the forestry industry, however, is low throughout all stages from production to processing and distribution. This is because of the underdevelopment of infrastructure such as roads and communications, which leads to transaction costs becoming high. For this reason, the improvement of efficiency in the forestry industry, including small-scale enterprises, would bring great benefits to the economy and environment. ${ }^{59}$

\subsection{National debt}

Zambia's stock of external debt has been rising since 2012. At the end of 2014, external debt stock was at US\$4.81 billion, representing 24.0\% of GDP, compared to US $\$ 3.18$ billion which was $17.2 \%$ of GDP in 2012. In 2015, external debt was US $\$ 6.41$ billion, and in September 2016 the external debt had reached US\$6.7 billion, representing 35\% of GDP. By 2018, the debt had increased to $72 \%$ of GDP. ${ }^{60}$ The International Monetary Fund (IMF) predicts that if the country maintains its current path without fiscal policy adjustments, debt will increase to a high of $84 \%$ of GDP by 2021 , well above the threshold of so-called debt sustainability (very roughly the threshold is around $60 \%){ }^{61}$

The historical perspective to the foregoing is that, in 1991, Zambia moved from a single-party state dominated by the United National Independence Party (UNIP), to a multiparty state led by the Movement for Multiparty Democracy (MMD). The MMD inherited a huge public (or government) debt from the former ruling party, UNIP. At that time, the size of the debt was not known (mainly owing to impasses between the UNIP government and multilateral institutions like the IMF). After 1991, the MMD government's willingness to address the debt situation, coupled with their more

58 BoZ (2017b: 3).

59 Japan Association for International Collaboration of Agriculture and Forestry (2008: 39).

60 Ministry of Finance (2017: 19).

61 Personal communication with Ministry of Finance Economists (June, 2019). 
favourable stance on the IMF and World Bank, led to the establishment of the exact debt size by $2000 .{ }^{62}$ Around the same time, the MMD government and civil society, both in Zambia and internationally, mounted a vigorous debt forgiveness campaign called Jubilee 2000. At that point, the debt was estimated at K29.2 billion, which accounted for $261 \%$ of GDP (or more than two and a half times the size of the economy). ${ }^{63}$

Zambia reached the Highly Indebted Poor Country (HIPC) completion point in 2004 and a big chunk of its debt was written off. The debt burden fell from K38.6 billion (or 130\% of GDP) in 2004 to K28.2 billion (76\% of GDP) by $2005 .{ }^{64}$ The country had at that time attracted further debt relief under the Multilateral Debt Reduction Initiative (MDRI) and its debt dropped further to a moderate $25 \%$ of GDP. During the remainder of the MMD government era, there were sustained prudent fiscal and monetary policies, including tight debt management, thus reducing the debt to $19 \%$ of GDP by $2010 .{ }^{65}$ Zambia was assigned lower middle-income country status in 2011, along with Ghana, which facilitated extensive borrowing on the private markets $(\mathrm{Eu}-$ robonds) and numerous non-concessional loans from China. ${ }^{66}$

The year 2011 saw a regime shift to the Patriotic Front (PF) government. The then new government inherited a healthy economy with a good fiscal position. The national debt increased sharply from $21 \%$ of GDP in 2011 to a remarkable $62 \%$ in 2015 . In the interim, the government had, among other things, borrowed three Eurobonds, one in 2012 worth US $\$ 750$ million, another in 2013 worth US $\$ 1$ billion and the third in 2015 worth US $\$ 1.25$ billion (making the total Eurobond issuance to US $\$ 3$ billion). ${ }^{67}$ Despite an economic downturn and GDP growth slowdown in 2015, the government kept borrowing, treating the downturn as a temporary thing, which it was not, as has been seen in the current debt burden and gloomy predictions. According to the IMF, this debt scenario is being fueled by the country's development strategy which has seen rapid scaling-up in infrastructure spending and consequent large fiscal deficits, financed by non-concessional debt. ${ }^{68}$

See https://www.oecd.org/countries/zambia/2497663.pdf; https://www.afdb.org/fileadmin/uploads/afdb/Documents/Generic-Documents/Zambia_Country_Profile.pdf, both accessed 2 February 2021.

63 See https://jubileedebt.org.uk/countries/zambia, accessed 2 February 2021.

64 IMF (2005).

65 AFRODAD (2003: 11-15).

66 Hinfelaar \& Sichone (2019: 6).

67 Nalishebo (2015).

68 Hinfelaar \& Sichone (2019: 5-6). 
Foreign investments in developing economies such as Zambia mostly hinge on natural resources exploitation, which in turn may have adverse environmental effects. Some of these adverse environmental effects affect soil quality, for instance in mining. Foreign direct investment (FDI) is an important source of development in most countries as it facilitates access to international markets, the creation of more skilled jobs, and technological and innovative advancements. ${ }^{69}$

Research conducted by the central bank on foreign assets and liabilities during the period 2016-2017 provided highlights on the magnitude, types and direction of foreign private capital assets and liabilities, Foreign Affiliates Trade in Services (FATS) and investor perceptions in Zambia. ${ }^{70}$ It was found that Zambia's net foreign direct investment inflows declined by $58.7 \%$ to US $\$ 486.1$ million from US $\$ 1,177.4$ million in 2015, mainly explained by a reduction in FDI liabilities by $49.2 \%$ to US $\$ 662.8$ million from US $\$ 1,304.9$ million. ${ }^{71}$ Net acquisition of FDI assets, however, rose by $38.6 \%$ to US\$176.7 million. The fall in FDI liabilities was largely driven by reduced growth in foreign borrowing from related parties and retained earnings in various industries. ${ }^{72}$

Value addition in the mining and manufacturing industries improved. Borrowing from affiliates continued to be the major form of FDI liabilities, with British Virgin Islands as the major source country, accounting for $37.0 \%$ of the total inflows, while the manufacturing industry was the major recipient of the inflows. In 2016, Zambia's private sector foreign assets transactions increased by $94.9 \%$ to US $\$ 407.5$ million explained by an increased accumulation of assets in other investments and direct investments. Switzerland was the major destination, accounting for $87.7 \%$ of the flows, largely for the mining and quarrying industry. As noted throughout this report, mining is the mainstay of the Zambian economy ${ }^{73}$ despite intense efforts at diversification.

In a report examining how Zambia can leverage the benefits and mitigate the risks of Chinese foreign direct investment to support its long-standing objective of diversified growth, it was found that: ${ }^{74}$

Zambia needs foreign capital to catalyze diversification, while China is seeking destinations and projects that will generate profits; the intersection of which may constitute a viable Zambian growth strategy, provided the country can both attract Chinese FDI and ensure that the domestic economy benefits from the investments.

For the purposes of this research, diversification was taken as "an effort to target investment in and modernization of priority non-mining sectors that have hitherto been

Ibid.

Ndaba (2015: 7).

Abdelghaffar et al. (2016: 10). 
underdeveloped - in particular agriculture, manufacturing, energy, transport and infrastructure." 75

In line with Zambia's development agenda after 2017, a successful implementation of the diversification strategy stimulated growth and created jobs in these sectors of the economy. Investment opportunities included potential for manufacturing based on agricultural produce as inputs for crop-processing plants, such as canning factories and oil-processing plants. Further, large tracts of land have been reserved as farming blocks earmarked for large-scale farming and, in such areas, government is providing basic infrastructure such as feeder roads, communication and power. ${ }^{76}$ In the mining sector, exploitation of gold, zinc, coal, nickel and gemstones (emeralds, aquamarine, topaz, opal, amethyst) offers great opportunities for potential investors.

The organisational structure discussed in this section is important for understanding the enforcement of soil-relevant laws and policies in Zambia.

The Constitution establishes Zambia as a "sovereign Republic under a constitutional form of governance." basic postulates of a free society", meaning that it establishes "the basic structure of government ..." ${ }^{78}$ The present Patriotic Front government has been in office since September 2011, with changes in leadership owing to death in 2008 and 2014. The next general elections are scheduled for 2021. ${ }^{79}$

The Republic of Zambia is a unitary, multiparty democracy with a distinct separation of powers between the executive, legislative and judicial arms of government and an executive president. ${ }^{80}$ The President and members of parliament are elected by the people through direct elections; ${ }^{81}$ and the President in turn appoints cabinet ministers from the elected and nominated members of parliament. Zambia has a unicameral parliament, which is presided over by the Speaker of the National Assembly, while the Judicature of Zambia is headed by the Chief Justice. ${ }^{82}$

75 Ibid.: 4.

76 ZDA (2017).

77 Article 4(1) and (2).

78 Ndulo \& Kent (1996: 256).

79 Prizzon (2013: 4).

80 Article 4(3) of the Constitution (2016).

81 Article 47(1).

82 The Commonwealth: (2019). 


\subsection{Legal system / tradition}

Zambia has a dual legal system in which written law operates side by side with customary law. ${ }^{83}$ Other authors have also described the country's legal system as "deeply plural" in its nature owing to its colonial past. ${ }^{84}$ The Constitution of Zambia (Amendment) Act, No. 2 of 2016 provides that the laws of Zambia consist of the Constitution, laws enacted by Parliament, statutory instruments, Zambian customary law that is consistent with the Constitution and the laws and statutes, which apply or extend to Zambia, as prescribed. ${ }^{85}$

Customary law is generally administered by lower courts in the judicial hierarchy and it consists of matters of a personal nature, such as marriage, inheritance and land. ${ }^{86}$ In the context of land, it must be emphasised that this law only applies with respect to customary tenure. It is interesting to note that matters of soil sustainability would most likely be addressed under written environmental law, regardless of the fact that the land in question is subject to customary tenure. Customary laws are not codified and as such the phrase 'customary law' does not refer to a single system but instead a set of rights, liabilities and duties across diverse ethnic groups. ${ }^{87}$

According to Munalula, the case of English law in Zambia, like other former British colonies, is different from the legacy inherited by former French colonies: English law was "never imposed ... in such a way as to oust the indigenous customary law." 88 Common law utilises a system of judicial precedent which binds judges to prior decisions and doctrines developed over time by judges in earlier and more superior courts, rather than being derived exclusively from statutes or legislation. As such, judges determine the answers to legal questions through the review of previous judicial decisions and accordingly build analogies to the facts of the case before them ${ }^{89}$ In Zambia, common law is generally administered in the hierarchically higher courts, known as superior courts and in which both civil and criminal cases are heard, as well as appeals from the first instance courts.

Most Zambians resort to applicable customary law in case of disputes. This is attributable to the fact that almost $60 \%$ of the Zambian population resides in rural and peri-urban areas, where the majority of traditional and local courts are situated. ${ }^{90}$ Against this background, some authors conclude that statutory courts are therefore "irrelevant" for a sizeable part of the population. ${ }^{91}$

83 Munalula (2004: 54).

84 Gloppen (2003: 11); Ige (2015: 59).

85 Article 7.

86 Gloppen (2003: 113).

87 See https://issafrica.org/chapter-6-customary-justice, accessed 5 February 2021.

88 Munalula (2004: 53).

89 Church (1974: 2).

90 AFRONET (1998).

91 Gloppen (2003: 131). 
As a core feature of the country's legal system, the Judiciary is created under the Constitution as a neutral and independent arbiter, thus: "in the exercise of the judicial authority, the Judiciary shall be subject only to this Constitution and the law and not be subject to the control or direction of a person or an authority."92 According to Article 120(1), the Judiciary consists of the superior courts and subordinate courts, small claims courts, local courts, and courts as prescribed. The superior courts are the Supreme Court, Constitutional Court, Court of Appeal, and High Court. Article 121 provides that the Supreme Court and Constitutional Court rank as equivalents.

\subsection{Competence of legislation and enforcement}

Zambia has a unicameral parliament that consists of the President and members of Parliament. According to Article 61 of the Constitution, the legislative authority of the Republic derives from the people of Zambia and is exercised in a manner that protects the Constitution and promotes democratic governance. Parliament consists of the President and the National Assembly. The Constitution provides that the legislative authority of the Republic is vested in and exercised by Parliament, ${ }^{93}$ and further that no person or body, other than Parliament, has the power to enact legislation, except as conferred by the Constitution. ${ }^{94}$ Article 63(1) provides that in exercise of its legislative function, Parliament enacts legislation through bills passed by the National Assembly and assented to by the President. Article 64(1) empowers a member of Parliament or Minister to introduce a bill in the National Assembly.

The legislative-making powers of Parliament have been subject to judicial interpretation in the past giving the Supreme Court an opportunity to assert the legislative power of Parliament in the Zambia Democratic Congress $v$ Attorney-General. ${ }^{95}$ This was an appeal case against the judgement of the High Court dismissing the appellant's application for judicial review. The original application for judicial review challenged the decision by the President and the Cabinet to amend the Constitution in the manner suggested in Constitution of Zambia (Amendment) Act, No. 17 of 1996, which was published in the Government Gazette as required by Article 79 of the Constitution. The applicants averred that the change sought to alter or destroy the basic structure or framework of the Constitution. The Supreme Court held that the Constitution of Zambia itself gives Parliament powers to make laws and that Parliament could not be equated to an inferior tribunal or body when exercising its legislative powers. In

92 Article 122(1).

93 Article 62(2).

94 Article 62(3).

95 SCZ Judgment No. 37 of 1999. 
appropriate cases, however, actions, but not by judicial review, could be commenced against it.

The enforcement of the legislative framework in Zambia is performed by various law enforcement agencies and any other authorised persons under the various applicable laws. Most of the soil-relevant legislative provisions analysed in this report are subject to enforcement by the Zambia Environmental Management Authority (ZEMA) established under the Environmental Management Act (EMA), 2011.

\subsection{Role of traditional entities}

Traditional leaders in Zambia play a vital role in the administration of customary law generally and, more specifically, land rights, which are critical to the soil sustainability discussion in this report.

Historically, all the constitutional regimes in Zambia since 1965 have recognised the role of traditional authorities in national affairs. The current Constitution recognises the role of traditional entities in Zambia. Article 165(1) provides that the "chieftaincy and other traditional institutions are guaranteed and shall exist in accordance with the culture, customs and traditions of the people to whom they apply." Further, in support of the existence of these traditional institutions, Parliament will not enact legislation which "confers on a person or authority the right to recognize or withdraw the recognition of a chief or derogates from the honour and dignity of the institution of chieftaincy." 96

The institution of chieftaincy is recognised in Article 166 as a "corporation sole with perpetual succession and capacity to sue and be sued and has capacity to hold property in trust for its subjects." The administration of traditional land has been highlighted as one of the major challenges that the traditional leadership in Zambia faces. Most of the contention surrounding this provision relates to land and resources that are land-based. In this context, soil sustainability interests are also affected. It is arguable that the chiefs must exercise leadership and decision-making powers related to ensuring the well-being of the natural resources they hold in trust for their subjects.

Further, a chief may own property in a personal capacity and is constitutionally empowered to enjoy privileges and benefits either bestowed on the office of chief by or under culture, custom and tradition and/or attached to the office of chief, as may be prescribed.${ }^{97}$ Furthermore, the Constitution allows chiefs to participate in the running of public affairs by seeking and holding public office, provided they abdicate the chief's throne, in all cases, except in the case of appointment as councillor. 
Of further relevance to this discussion, the Constitution provides that the role of a chief in the management, control and sharing of natural and other resources in the chiefdom will be prescribed. ${ }^{98}$ There is no further information of this detail in the Constitution, except in the provisions of The Chiefs Act, which is discussed below.

Article 169 establishes a House of Chiefs to consist of five chiefs from each province, elected by the chiefs in that Province. The functions of the House of Chiefs are to:

(a) consider and discuss Bills relating to custom or tradition referred to it by the President, before the Bill is introduced into the National Assembly; (b) initiate, discuss and make recommendations to the National Assembly regarding socio-economic development in the Province; (c) initiate, discuss and decide on matters relating to customary law and practice; (d) initiate, discuss and make recommendations to a local authority regarding the welfare of communities in a local authority; (e) make proposals on areas in customary law that require codification; (f) advise the Government on traditional and customary matters; and $(\mathrm{g})$ perform other functions as prescribed. ${ }^{99}$

The preamble to the Chiefs Act, Chapter 287 provides that it is purposed to make provision for the recognition, appointment and functions of chiefs and their deputies, and other incidental matters. Historically, chiefs and traditional authorities have been active participants in natural resources management in Zambia. ${ }^{100}$

Section 3 outlines the chiefs who are recognised in Zambia, while Section 10 outlines the chiefs' functions:

The traditional functions under African Customary Law in so far as the discharge of such functions is not contrary to the Constitution or any written law and is not repugnant to natural justice or morality and such functions as may be conferred or imposed by this Act or any other written law.

In practice, this provision applies by operation of unwritten customary law, and provisions of written law such as the Local Government $\mathrm{Act}^{101}$ and the Registration and Development of Villages Act, both of which ensure that chiefs and other traditional leaders are involved in the management of natural resources generally in the rural areas where most of their jurisdiction applies.

The general view of traditional leaders over time has been that their traditional authority is at best ignored in land transactions involving large-scale investment. For instance, it has been observed that potential investors usually acquire land only to resell it at exorbitant prices, sometimes without ever developing it. The House of Chiefs, in line with its constitutional mandate, has in the past proposed that the Ministry of Lands needed to be strengthened at provincial level by increasing personnel so that it could undertake periodic land development inspections in all districts. ${ }^{102}$ This would

98 Article 68(3).

99 Article 169(5).

100 Munyinda \& Habasonda (2013: 24-27).

101 Sections 36 and 37.

102 Zambia Environmental Management Agency (2017: 41-57); Ministry of Lands and Natural Resources (2017). 
hopefully compel investors to develop the land within a specified period. It has further been proposed that standard guidelines be developed on acquiring land from traditional leaders across the country, to improve land administration. ${ }^{103}$

Another area of concern for traditional leaders is the high poverty levels in rural districts and it has accordingly been proposed that government should put in place policies to ensure that rural areas are opened up for development by ensuring that essential services such as electricity, transport network, schools and hospitals are available. $^{104}$

\subsection{Religious considerations}

Article 4(3) of the Constitution provides that "the Republic is a unitary, indivisible, multi- ethnic, multi-racial, multi-religious, multi-cultural and multi-party democratic State." The multi-religious nature of the Zambian population is confirmed by statistics, which indicate that Protestants comprise $75.3 \%$ of the total population, Roman Catholics 20.2\%, others 2.7\% (which includes Muslims, Buddhists, Hindus and Baha'i), while $1 \%$ covers the non-religious. ${ }^{105}$

Each of the country's religions have an approach towards soil and environmental protection. In a 2016 newspaper article, it was reported that government had declared that there was need for more organisations to promote organic farming among farmers in order to protect the environment from chemical fertilizers and improve yields. ${ }^{106}$ Organic farming promotes the natural regeneration of humus in the soil thereby helping the earth to support growth that feeds living organisms on the land.

Speaking at a conference under the theme: "Care of our common home in the context of large- scale investments: mining and agriculture," the Deputy Minister of the then Ministry of Lands, Natural Resources and Environmental Protection had said that government recognised and appreciated the work that the Catholic Church had continued doing in Zambia, in terms of promoting organic farming among small-scale farmers. Government went on recommend the Catholic Church for running the Kasisi Agricultural Research Institute, which was spearheading the promotion of organic farming among small-scale farmers by teaching them how to improve their yields without doing harm to the soil through the use of chemical fertilizers.

In the previous year, 2015, Pope Francis had called on all people to "enter into dialogue about the common home planet [E]arth to [promote] environmental management."107

103 World Bank (2016: 7-10).

104 See generally Ministry of Chiefs and Traditional Affairs (2016).

105 See https://www.indexmundi.com/zambia/religions.html, accessed 5 February 2021.

106 Tembo (2016).

107 Pope Francis (2015); van Tine (2017: 141-178). 
Further, the government shared the concerns expressed by Pope Francis on the plight of the earth and the need to take action and was committed to protecting the environment. The government effected several policies, strategies and programmes to help manage the environment and natural resources prudently.

Some of the policies and legislation were to ensure that development actions, including mining and other extractive industries, did not result in environmental liabilities. This newspaper article shows that from the Christian Catholic perspective, soil conservation and environmental protection are important considerations.

Furthermore, in 2018, the Catholic Church augmented practical measures towards soil conservation by coining the "Prayer for the year of the environment, 2018," which was recited on every day of prayer throughout that year. The acts of praying faithfully and actually taking practical steps towards environmental protection from the religious perspective is one way of ensuring that more community members are aware of the urgent need to preserve the environment for future generations.

The perspective of the Catholic Church is reinforced by the argument of Hansjürgens that soil is of central importance to the global provision of food and in the fight against hunger, climate change, loss of biodiversity and deterioration of water bodies. The author traverses the other legal and ethical considerations and concludes that: ${ }^{108}$

More than ever, sustainable soil conservation requires (improved) social integration. Soil is not only part of God's creation, but also constitutes valuable "natural capital" from an economic perspective, that is worthy of protection.

This conclusion can be taken as a summation of the position of all other Christian denominations in relation to soil preservation. In relation to other religions, the belief that a higher being or force created the universe and all things contained therein would be taken as the basis for ensuring that the environment and its constituent components such as soil are well maintained. The responsibility for caring for the environment would naturally rest on human beings as custodians.

This section analyses the main drivers of soil degradation in Zambia. The main constraints to sustainable soil management in the country have generally been identified as soil erosion and degradation and are also closely linked to deforestation. In addition, the huge energy deficit in the country has brought renewed pressure on wood fuel and consequently on sustainable soil management.

Soil erosion refers to the wearing away of a field's topsoil by the natural and physical forces of water and wind, or through farming activities such as tillage. ${ }^{109}$ Soil 
erosion is a natural, essential process for the formation of soil. ${ }^{110}$ As a naturally occurring phenomenon, soil erosion affects all landforms. It occurs when soil is removed through the action of wind and water at a greater rate than it is formed. Erosion involves the three distinct actions of soil detachment, movement and deposition, whether it is caused by water wind or tillage. ${ }^{111}$ Soil erosion has occurred throughout the history of agriculture; however, in recent years the rate at which soil is eroding has intensified and, as such, it is one of the major causes of land degradation. ${ }^{12}$

The concerns related to erosion as a factor contributing to the degradation of soil are due to the accelerated rate at which it is taking place, where the natural rate at which it ordinarily occurs has been significantly increased mostly by human activity. ${ }^{113}$ In relation to the agricultural use of land, land degradation involves deterioration in soil properties related to crop production. ${ }^{114}$

In addition to the foregoing, other industrial sectors such as manufacturing also have significant impact of soil health. For instance, some manufacturing processes involve the use of various chemical processes which may contribute to soil contamination, especially where there are ineffective waste management mechanisms. On another limb, the increased role of foreign investors across many economic activities may possibly lead to spiral effects of land and soil degradation.

Other sectors such as tourism may also put pressure on soil. Tourism is dependent on natural and man-made environmental quality. This means that tourism and the environment sustain a delicate relationship. On one hand, tourism puts significant stress on land-use practices, soil erosion, pollution, natural habitat loss and, on the other, potentially contributes to environmental protection and conservation, and raises environmental awareness and economic importance of natural areas. ${ }^{15}$

\subsection{Mining and soil sustainability}

Despite the economic benefits associated with mining activities, there are a number of negative impacts. The mining industry exerts enormous pressure on land and soil resources in the country. It has been noted that the mining sector has contributed to the contamination of soils and vegetation through dust fall-out from smelters, crushers and dry beaches of tailing impoundments. ${ }^{116}$ Additionally, quarrying activities in Zambia

110 Stanchi et al. (2015: 403-408).

111 Ul Zaman et al. (2018: 1116).

112 Pimentel \& Kounang (1995) 1117.

113 Stanchi et al. (2015: 403).

114 Alori \& Nwapi (2014: 98-114).

115 Sunlu (2003: 263-270).

116 Kř́bek et al. (2008: 24-26). 
have been acknowledged to be increasing as a result of heightened demand for aggregate materials for use in construction.

Although quarrying has brought socioeconomic benefits especially for the informal sector, uncontrolled and illegal quarrying, particularly in urban areas, has resulted in negative environmental impacts including land degradation and groundwater quality deterioration. ${ }^{17}$ The resultant effects include soil contamination; air, ground- and surface-water pollution; formation of sinkholes; erosion; and loss of biodiversity. Other notable environmental impacts include deforestation and the formation of acid rain, which results from sulphur dioxide emissions reacting with rain in the atmosphere to form weak acid. This correspondingly reduces soil fertility and compromises crop production. ${ }^{118}$

\subsection{Unsustainable agricultural practices}

Other causes of soil degradation are non-sustainable cultivation practices such as cultivation rows which run parallel to a slope resulting in automatically concentrating water flow in a manner that produces soil erosion. Traditional cultivation systems like shifting cultivation or 'slash and burn' also have a negative impact on the environment and result in soil degradation. When the yield declines, a new area is cleared for shifting cultivation, and the initial site is left to lie fallow.

Soil acidity is also a serious problem, particularly in the heavily leached soils of the higher rainfall zones of northern Zambia. Phosphates become insoluble and unavailable to the plants even when present in the soil under conditions of high acidity. ${ }^{119} \mathrm{Ac}$ cording to the Ministry of Water Development, Sanitation and Environmental Protection, it is estimated that acidification due to fertilizer accounted for the loss of up to $15 \%$ of arable land in 20 years in the Northern Province. ${ }^{120}$ Although the use of nitrogen fertilizer increases soil organic matter, there are cases where continuous use of nitrogen fertilizer destabilises the clay soils and enhances pan formation, which impairs plant root growth while up to $80 \%$ losses in organic matter may occur. ${ }^{121}$

\subsubsection{Overstocking and overgrazing of animals}

Other causes of soil degradation and soil erosion are bush fires and overstocking of and overgrazing by livestock. Bush fires are not necessarily linked to overgrazing and

117 ZEMA (2017: 84); Dymond, et al. (2007: 19-22).

118 ZEMA (2017: 84).

119 Chidumayo (1987: 15-18).

120 Blackwell et al. (1991).

121 Ibid.; ZEMA (2017: 47). 
overstocking of animals. According to research, bush fires are deliberately started in certain regions of central to northern Zambia as a traditional practice over many years. ${ }^{122}$ Eriksen argues that bush fires are: ${ }^{123}$

a major feature in the seasonal land management calendar ... the local communities use fire to obtain desired natural resources and to shape the natural environment and further their agricultural and other objectives, such as bush clearance, fire break creation, charcoal production, hunting, weed and disease control, caterpillar breeding, honey collection and pasture regeneration.

From the foregoing, it is clear that local communities appreciate the direct benefits of bush fires to their immediate needs but are oblivious to the long-term adverse effects of bush fires on soil sustainability.

In Zambia, both wild and domestic animals, which are carnivorous, herbivorous and omnivorous abound. The keeping of domestic animals and the presence and keeping of significant numbers of herbivorous and omnivorous wildlife in the country means that there is pressure on grazing lands. The use of land for human activities such as crop farming in most rural areas and mining have also placed added pressure on grazing land and in some cases has resulted in overstocking and overgrazing of land, with adverse effects on ecosystems, notably, wildlife depletion and loss of biodiversity. ${ }^{124}$

Overall, livestock accounts for about $35 \%$ of the national agricultural output and is mainly concentrated in the Western and Southern Provinces of the country. The animal population comprises largely of goats and cattle, whose numbers have been rising steadily over the years. ${ }^{125}$ With increased animal populations, the carrying capacity of most rural communal land has become inadequate, and thus susceptible to overuse, leading to land and soil degradation.

In addition to the natural factors, such as water and wind, that cause soil erosion, several human activities have contributed to soil erosion, and are the major cause of the accelerated rate at which soil is eroding. ${ }^{126}$ Erosion caused by human activities occurs with farming practices that are not compatible with the fact that soil can be washed away or blown away. In Zambia, one of the major causes of soil erosion and degradation is deforestation caused by the practice of clearing new land for agriculture when old fields lose their fertility. This is practised under the traditional 'slash and burn' Chitemene system of shifting cultivation. ${ }^{127}$

Chitemene is the main traditional agricultural system that has adversely affected soil health in Zambia. Chitemene is a Zambian Bemba word which refers to the system of slashing and burning agricultural vegetation. The system is widely practised throughout northern Zambia and is known to have contributed to the loss of half the Miombo

122 Eriksen (2007: 242-247).

123 Ibid.: 249.

124 ZEMA (2017: 84).

125 Ibid.: 48.

126 Ul, Zaman (2018: 1114).

127 Eriksen (2007: 243-248). 
woodlands, closely followed by charcoal burning. ${ }^{128}$ While governments, donors and other stakeholders have expended huge sums of money in order to reduce climate change, land degradation and deforestation, old farming methods are still being practised by most small scale farmers. ${ }^{129}$ Further, about $90 \%$ of deforestation in Zambia is attributable to clearing of land for agricultural purposes, especially through the Chitemene system of farming. ${ }^{130}$

Arguably, the continued practice of the Chitemene system is, in the long term, unsustainable. As the rural population continues to grow, complete deforestation may occur in the coming decades. It is also estimated that northern Zambia has lost more than $35 \%$ of its biomass as a result of the Chitemene farming system, representing a total of about 43,000 square kilometres of forest land over the past 40 years. ${ }^{131}$ It has further been observed that with the number of small-scale farmers engaged in this practice, there is no doubt that the impact that is left on the environment is vast and devastating. ${ }^{132}$

The additional adverse effects of the Chitemene system include loss of biological diversity within the forests, increased water runoff and soil erosion, and soil fertility depletion due to the leaching of nutrition. Apart from wildlife depletion, soil erosion and a settlement problem, deforestation is one of the major environmental problems arising from Chitemene. ${ }^{133}$

Although the slash and burn system may lead to a more fertile soil in the form of ashes in the short term and therefore compare favourably to inorganic fertilizers purchased at high cost, those temporary benefits cannot outweigh its devastating longterm effects. ${ }^{134}$ Slash and burn, shifting cultivation has been the dominant traditional land use in the Miombo woodlands of northern Zambia. This type of cultivation is characterised by short cropping periods of two to six years which are followed by long fallow periods of ten to twenty years. ${ }^{135}$ These periods are too short for the indigenous species of trees to grow and mature to replace the trees originally felled.

\subsubsection{Wrong use of fertilizers and pesticides}

In Zambia, agriculture is largely classified into: (a) traditional agriculture mainly for producing subsistence food; and (b) commercial agriculture basically for commercial

128 ZEMA (2017: 51).

129 See http://www.bailiffafrica.org/the-extent-of-slash-and-burn-agriculture-in-zambia-byclifford-malambo/, accessed 15 April 2019.

130 Ibid.

131 Engel et al. (2017: 13).

132 Ministry of Lands and Natural Resources (2017: i-iii; 1-5); Young (1989: 11-17).

133 Ministry of Lands and Natural Resources (2017).

134 Chidumayo (1987: 15-18).

135 Neubert et al. (2011: 91-100); Gumbo et al. (2018: 12-21). 
production. This dual structure of agriculture can be traced back to the economic structure formulated during the colonial era. Against this background, the general system of agriculture that has developed places heavy reliance on the use of non-organic fertilizers which ultimately cause environmental damage and soil degradation in themselves and when coupled with wrong usage. ${ }^{136}$ The use of pesticides which leech into the soil is also a hazard in relation to soil sustainability: ${ }^{137}$

Usage of pesticides, insecticides and other various chemicals in agriculture is very easy, quick and inexpensive solution for controlling weeds and insect pests. However, use of chemicals comes with a significant cost. They have contaminated almost every part of our environment and their residues are found in soil, water, land and air.

In order to boost agricultural output, a shift of cultivation methods from indiscriminate chemical fertilizer usage to conservation farming is currently being advocated in Zambia. Among the manifold efforts to facilitate a change towards more sustainable and climate-smart farming practices, conservation farming is the most prominent.

Conservation farming aims at improved soil and water conservation combined with reduced dependence on chemical fertilizers resulting in increased and more stable yields. ${ }^{138}$ Further, conservation farming restores soil fertility damaged by years of continuous ploughing, and the application of destructive inorganic fertilizers. These soil conservation techniques are however not being undertaken on the basis of legislative coercion. It is worth restating here that the agricultural legislation has been earmarked for review to bring it in line with the projected 2030 developmental agenda for the country. It is expected that once this is achieved, the relevant legislation will incorporate international best practices in the use of inorganic fertilizers.

\subsection{Deforestation}

Zambia is one of the Southern African countries that has a large area of forests totalling an area of 45,610 hectares, which accounts for about $60 \%$ of the total land area $\left(752,600 \mathrm{~km}^{2}\right)$ of Zambia. It is acknowledged that within the forest area, the government, on a priority basis, carries out forest conservation in the forest reserves and national parks. ${ }^{139}$

The forest vegetation in Zambia is largely classified into two groups, the first consists of closed forests, mainly comprising evergreen trees of the cryptosepalum and deciduous trees of the baikiaea, while the second group is the open forests sometimes called the Savanna woodlands. ${ }^{140}$ This accounts for $87.5 \%$ of the total Zambian forests,

136 Shitumbanuma et al. (undated).

137 Sharma \& Singhvi (2017: 677).

138 Engel et al. (2017: 13) ; Neubert et al. (2011: 87); Ayub (2020: 31-33).

139 Ministry of National Development Planning (2016: 5-6); Gumbo et al. (2018: 10-11).

140 Gumbo et al. (2018: 1-3). 
including the Miombo woodlands, the Kalahari woodlands, the Mopane woodlands and the Munga woodlands. ${ }^{141}$ One of the main causes of forest reduction and degradation is charcoal production, which is widely used by poor households in urban areas. ${ }^{142}$

Among these woodlands, the Miombo woodlands account for about $60 \%$ of the total forest area, constituting the main part of Zambian forests. This type of woodland is subject to the practice of the Chitemene system explained in the previous section. The Miombo woodlands are not limited to Zambia but cover the vast area of Southern Africa including Angola, Zimbabwe, Malawi, Mozambique, Tanzania, and the Democratic Republic of the Congo, thus the typical woodlands of the region. ${ }^{143}$

The government started reforestation in the 1960s. Although it was conducted on a pilot basis at the beginning, the area has over time, under industrial reforestation, covered over 55,000 hectares. Reforestation has been done through the planting of Pine (79\%) and Eucalyptus (20\%). ${ }^{144}$ However, new reforestation and its expansion are not enough to meet demand; consequently, the commercial reforested acreage is currently decreasing. It has been postulated that reforestation has substantially reduced the pressure on the native forests in Copperbelt Province, the main copper-producing area. ${ }^{145}$

Deforestation is presently exacerbated by the consumption of charcoal which is a major source of energy. This report has identified increased energy demand as a driver of soil degradation. As an ecological issue, the reduction in forests has become an increasingly serious problem owing to various causes including charcoal production, inadequate farming techniques, uncontrolled bush fires, uncontrolled forest cutting for construction uses, and overgrazing of animals as explained earlier in the previous sections. Moreover, the illegal cutting and unlawful trading of timber has further added to the problem of deforestation. It is estimated that about 250,000 hectares of forests are lost annually as a result of uncontrolled development of forestry products, illegal settlements and transfers from forests to farmlands. ${ }^{146}$ It has further been observed that Zambia's forests are under tremendous pressure, because the deforestation rate is well above the global and regional average. ${ }^{147}$ Additionally, deforestation threatens biodiversity and undermines key ecosystem services such as climate and water regulation. Shortened flow of seasonal streams and the drying up of formerly permanent rivers have also been observed. ${ }^{148}$

Throughout Zambia, degrading land resources and poor water management are serious impediments to the development of agriculture. This has a further impact on the

141 Japan Association for International Collaboration of Agriculture and Forestry (2008: 21).

142 Chidumayo \& Gumbo (2013: 86-89).

143 Ministry of Agriculture (2017: 1); Gumbo et. al. (2018: 1-3).

144 Chileshe (2001: 20).

145 Japan Association for International Collaboration of Agriculture and Forestry (2008: 25); Chileshe (2001: 20-23).

146 UNEP (2015: 12-25).

147 Mudenda (2010: 6); Ministry of National Development Planning (2016: 6); UNEP (2015: 12).

148 Gumbo et al. (2018: 2, 35, 44-48). 
quality of soil. Inappropriate farming practices have numerous negative impacts on soil, such as soil erosion, loss of soil organic matter, declining fertility, and capacity to retain water. Once fertile soils become compacted and crusted, they cause valuable rainwater to run off rather than seep into the ground, carrying with it precious topsoil and nutrients. The results are unhealthy crops due to water and nutrient deficits and the build-up of weeds and diseases, poor and unreliable yields, and chronic water shortages resulting from lack of recharge of groundwater. ${ }^{149}$

\subsection{Climate change effects}

Climate change is presenting significant challenges the world over, although, in the case of Zambia, these have not been directly related to soil sustainability. It is recognised in the country's National Policy on Climate Change that:

evidence shows that Zambia has, over the past years experienced a number of climate related hazards, including droughts and dry spells, seasonal and flash floods, and extreme temperatures (...) and have adversely impacted on food and water security, energy and livelihoods of communities, land degradation and desertification. ${ }^{150}$

The meaning of this realisation from the scientific perspective is that natural resources, more specifically soil and ecosystems, are under serious threat. By way of recapitulation, soil is the basis of entire ecosystems and services, and having climate-related hazards such as droughts and dry spells, among others, creates an unfavourable environment for sustainable soil management.

From the global perspective, the Intergovernmental Panel on Climate Change (IPCC) defines climate change as "a change in the state of climate that can be identified (statistics test by the mean/and or variability of its properties that persists for an extended period, typically or longer." 151 It refers to any change in climate over time, whether due to natural variability or human activity. Article 2 of the United Nations Framework Convention on Climate Change, to which Zambia is a party, refers to "a change of climate indirectly or directly as a result of human activity that alters the composition of the global atmosphere and that in addition to natural climate variability observed over comparable time periods." 152

From the local perspective, addressing the effects of climate change is one of the core features that has direct relevance to soil sustainability in Zambia. Adaptation is also key in the country context, being defined as "adjustment to natural or human

149 Mudenda (2010: 7).

150 Ministry of National Development Planning (2016: 2).

151 See https://unfccc.int/files/press/backgrounders/application/pdf/press_factsh_science.pdf, accessed 3 February 2021.

152 See https://unfccc.int/resource/ccsites/zimbab/conven/text/art01.htm, accessed 3 February 2021. 
system in response to experience or future variability and extreme events which may be beneficial or adverse." 153

Previously, Zambian institutions considered climate change using different lenses. For instance, the Ministry of Finance focused mainly on disaster risk management and economic growth, framing the environment as a "reservoir of natural resources which could provide an impetus to economic development" 154 By contrast, the Ministry responsible for the environment proposed a more holistic perspective of "equal and sustainable management of resources and on climate change, maintained the mission is to ensure that the most vulnerable sectors of the economy are climate proofed." 155

\subsection{Poverty and demographic growth}

Since attaining political independence, Zambia has had mixed economic fortunes as a result of the policies that the country has pursued. More recently, it has been observed that although the country recorded steady economic growth during the period 19902015 , poverty remained the greatest challenge to national development. ${ }^{156}$ It has further been observed that poverty trends suggest that, overall, income poverty prevalence was reduced between 1991 and 2015 by $24.6 \%$, although an increase was observed in the late $1990 \mathrm{~s}$. The reduction in poverty was more significant in urban areas, where it declined by $25.6 \%$, from $49 \%$ in 1991 to $23.4 \%$ in 2015 . Income poverty in rural areas decreased from $88 \%$ to $76.6 \% .{ }^{157}$

The impact of population growth on soil sustainability is intertwined with the agricultural and industrial practices relating to land use in Zambia. It must be noted that since only $10 \%$ of land in Zambia is under statutory tenure and about $90 \%$ is customary law, the increasing urbanisation means that there is more pressure being placed on the land. If the practices that have a negative impact on soils are not changed or resolved, then the impact on soils and the environment generally will be extremely grave.

Furthermore, the increasing population has placed pressure for settlement on ecologically sensitive areas such as wetlands and game management areas, affecting both customary and statutory land. These settlements have also had an impact on the generation and disposal of waste. According to ZEMA, ${ }^{158}$ improper waste disposal has contributed to pollution through soil, water and air contamination. The concomitant

153 Ministry of National Development Planning (2016: v, 12-13).

154 Ministry of Finance and National Planning (2011), this Ministry has now been split into two, namely the Ministry of Finance and the Ministry of National Development Planning.

155 Ministry of Tourism Environment and Natural Resources (2010: ii), which was also split into Ministry of Tourism and Arts, Ministry of Water Development, Sanitation and Environmental Protection and Ministry of Lands and Natural Resources.

156 Ministry of National Development Planning (2017: 13).

157 Central Statistical Office (2016: 9).

158 ZEMA (2017). 
effects of this have included public health challenges such as the outbreak of diseases like dysentery and cholera; expenditure and infrastructure challenges resulting from the need for water treatment and addressing blockages in drainage systems, which also accelerates infrastructural damage to roads. Overall, this has contributed to the proliferation of pests and vermin, and the loss of aesthetic beauty.

According to official statistics, the percentage distribution of the population by level of poverty in 2015 showed that $40.8 \%$ of the population was extremely poor, while $13.6 \%$ was moderately poor. ${ }^{159}$ The proportion of the non-poor was $45.6 \%$. With the 2015 projected national population at 15.9 million, this meant that 8.5 million people lived in poverty, with 3.5 million of those living in extreme poverty. ${ }^{160}$ It is clear that economic growth did not translate into significant poverty reduction, especially in rural areas. ${ }^{161}$

It has been observed that the pattern of economic growth in Zambia is highly unequal and has not increased the incomes of the poor rapidly enough to lift them out of poverty, mainly for three reasons. First, economic growth has historically been concentrated in capital-intensive industries such as construction, mining and transport. Secondly, and in relation to the geographical component of growth, urban areas have gained more than rural areas. Thirdly, and in relation to the structure of the economy, economic growth in the country has not been associated with labour-intensive sectors in which the poor tend to work, such as agriculture. ${ }^{162}$

\subsection{Urbanisation}

Zambia is one of the most urbanised sub-Saharan African countries, with $42.1 \%$ of the population living in urban areas. ${ }^{163}$ Urbanisation in Zambia is characterised by linear growth along the line of rail, where most urban centres are located - the largest being Lusaka, Ndola and Kitwe. Urban residents generally have relatively better access to public services and infrastructure compared to their rural counterparts and experience greater development, resulting in clear distinctions in human settlements between urban and rural areas and between different regions of the country. ${ }^{164}$ The high levels of urbanisation place immense pressure on the government to find land for new settlements, and at times at the expense of land designated for ecological preservation such as forests and protected areas.

159 See www.stats.gov.zm for this and further information.

160 Central Statistical Office (2016: 23).

161 Ministry of National Development Planning (2017: 11).

162 Ministry of Finance (2017: 5).

163 Mususa (2012: 571-573); Osei-Hwedi (1996); Huth (1984: 1-16).

164 Ministry of Finance (2017: 35). 
Water scarcity is already a major problem for the world's poor. The number of people affected by water scarcity is projected to increase from about 1.7 billion people at the present time to around 5 billion people by 2025. This is independent of climate change, which is projected to further reduce water availability in many water scarce regions, particularly in the subtropics, owing to increased evaporation and changes in rainfall patterns. Close to two million more Africans are expected to find themselves without adequate clean water as early as 2021. This will most likely lead to an increase in poverty and pandemics such as malaria and cholera. ${ }^{165}$ These public health concerns will further put pressure on natural resources such as water and soil. ${ }^{166}$

\subsection{Weak governance systems}

Weak governance systems across all the sectors has been noted as a key challenge affecting environmental well-being in Zambia. ${ }^{167}$ Some of the main deficiencies in the general environmental law framework and soil-relevant governance systems include gaps in policy frameworks and institutions, and poor linkages between those at the grassroots who are in direct contact with natural resources and state institutions that ultimately enact laws. ${ }^{168}$

In the forestry sector, weak levels of policy implementation have been identified as a challenge in the prevention of deforestation and forest degeneration, which in turn are a driver for soil degradation. In addition, in forestry, like other sectors, factors such as inadequate institutional capacity and legal framework and a lack of intersectoral coordination among stakeholders are responsible for hampering policy implementation generally. ${ }^{169}$ Other weaknesses in the environmental and soil governance systems include corruption and political influences, insecure land tenure and poor funding. ${ }^{170}$

In terms of the climate change debate, research in the context of Nepal, Uganda, Vietnam and Zambia has shown that: ${ }^{171}$

While there is little ambiguity within the science community regarding whether climate change is real, uncertainty concerning the implications of climate change in the policy arena is widespread among politicians and bureaucrats at all levels of governance. In our district-level cases we found widespread indecision over the implications of climate change for institutional roles and responsibilities. Most local government staff were introduced to the idea of climate change relatively recently. The international narrative of climate change that has filtered down to local

165 Mudenda (2010: 5-7).

166 Addaney et al. (2018: 182-184).

167 Reublic of Zambia (2009: 7).

168 Madzudzo et al. (2013: 10-11).

169 Kalaba (2016: 42-43).

170 Ibid.

171 Christoplos et al. (2016: 55-56). 
government staff is dominated by technical and infrastructural investment packages in which their own roles are ignored or undefined.

These research findings in the context of the named developing countries, which include Zambia, indicate that there are challenges in implementing climate change laws and policies. It has been shown in this report that the effects of climate change will lead to soil and land degradation. Accordingly, the challenges of implementing climate change laws and policies have a bearing on the argument for sustainable soil management in Zambia. Given the many sector-specific strides currently being undertaken, it is possible that enhanced and coordinated systems of monitoring and enforcement of environment-specific measures would also ultimately enhance sustainable soil management in Zambia. It is however hoped that, with the more coordinated approach towards climate change introduced by the National Climate Change Policy, these challenges and shortcomings will be resolved.

This section analyses the legislative framework relating to the main drivers of soil degradation in Zambia. This section starts by recapping that there are no legislative provisions dedicated to sustainable soil management in Zambia. However, there are many legislative provisions that relate to the conservation of biological diversity and environmental well-being and that are therefore relevant, by implication. The section specifically analyses relevant constitutional provisions and legislation related to mining, agriculture, land tenure and the environment, and natural resources.

\subsection{Constitutional provisions on soil sustainability}

To start with, the current Constitution is relatively new, having been enacted only in 2016. Therefore, most of the environmental provisions that can enhance soil sustainability in Zambia have not as yet generated any jurisprudence.

Article 147 of the Constitution makes provision for a devolved governance system. To this end, the concurrent and exclusive functions of the national, provincial and local government levels are outlined. Article 147(2) prescribes the annex of these functions, and the prevention of soil erosion is listed as a concurrent national and provincial function. 
Further, Part XIX of the Constitution contains provisions relating to land, environment and natural resources. ${ }^{172}$ The salient provisions of the Constitution relating to land are contained in Article 253, which provides that "land shall be held, used and managed" in accordance with the following principles: Equitable access to land and associated resources; security of tenure for lawful land holders; recognition of indigenous cultural rites; sustainable use of land; transparent, effective and efficient administration of land; effective and efficient settlement of land disputes; river frontages, islands, lakeshores and ecologically and culturally sensitive areas to be accessible to the public; not to be leased, fenced or sold; and to be maintained and used for conservation and preservation activities; investments in land to also benefit local communities and their economy; and plans for land use to be done in a consultative and participatory manner.

The entirety of Article 253 is critical in the promotion of the sustainable use of soil as it provides for the general principle for the sustainable use of land. This means that the use of land should be intergenerational in nature and should be predicated on the balancing of the various competing interests of society and the need to preserve the diversity and integrity of the country's flora and fauna. As was earlier alluded, it remains unclear how far this provision empowers state agencies in enforcing sustainable soil usage.

Article 255 of the Constitution is also instructive and relates to the management and development of the environment and natural resources, which will be governed by the following principles: Natural resources have an environmental, economic, social and cultural value and this must be reflected in their use. The person responsible for polluting or degrading the environment is responsible for paying for the damage done to the environment. Where there are threats of serious or irreversible damage to the environment, lack of full scientific certainty cannot be used as a reason for postponing cost-effective measures to prevent environmental degradation. The conservation and protection of ecologically sensitive areas, habitats, species and other environmental resources must be done in a sustainable manner. The integrity of natural processes and ecological communities must be respected. Benefits accruing from the exploitation and utilisation of the environment and natural resources must be shared equitably among the people of Zambia. Saving of energy and the sustainable use of renewable energy sources must be promoted. Reclaiming and rehabilitation of degraded areas and those prone to disasters must be promoted. Unfair trade practices in the production, processing, distribution and marketing of natural resources must be eliminated; and origin, quality, methods of production, harvesting and processing of natural resources must be regulated.

172 This covers Articles 253 to 257 of the Constitution; See also to Sambo (2019: 655-656) analysing these constitutional provisions in the light of their relevance in creating an 'environmental ethos' in Zambia. 
In relation to environmental sustainability, the Constitution also contains principles that are designed to prevent irreversible damage to the environment, such as Article 256 , which provides that a person has a duty to cooperate with state organs, state institutions and other persons to maintain a clean, safe and healthy environment; to ensure ecologically sustainable development and use of natural resources; to respect, protect and safeguard the environment; and to prevent or discontinue an act which is harmful to the environment.

The obligations placed on citizens under Article 256 are meant to ensure greater citizen social responsibility. These provisions are progressively being integrated into subordinate legislation such as the Solid Waste Management Act. The requirement to ensure ecologically sustainable development is especially important in order to ensure that the environment generally and soil and land generally are also sustainably utilised.

Article 257 makes provision for the state, in the utilisation of natural resources and management of the environment, as to protect genetic resources and biological diversity; to implement mechanisms that minimise waste; to promote appropriate environment management systems and tools; to encourage public participation; to protect and enhance the intellectual property in, and indigenous knowledge of, biodiversity and genetic resources of local communities; to ensure that the environmental standards enforced in Zambia are of essential benefit to citizens; and to establish and implement mechanisms that address climate change.

\subsection{Mining legislation}

The mining industry is governed by a number of pieces of legislation. This section focuses on the Acts of Parliament and subsidiary legislation that have relevance to sustainable soil management. The Mines and Minerals Development Act, No. 11 of 2015 (MMDA) is the main legislation governing mining in Zambia, read together with the Mines and Minerals Development (Amendment) Act, No. 14 of 2016, which reduced the percentage of royalties' payable on production of minerals. The MMDA applies to the exploration for, and mining and processing of, minerals and makes provision for safety, health and environmental protection in mining operations. In addition, the mining legal framework incorporates some statutory instruments. ${ }^{173}$ Of direct

173 Some of the subsidiary legislation include, but are not limited to (i) Mines and Minerals Development (Application for Mining Rights) Regulations SI No.123 of 1996 (ii) Mines and Minerals (Application for Mining Rights) (Amendment) Regulations SI No. 29 of 1997 (iii) Mines and Minerals Development (Environment Protection Fund) Regulations SI No. 102 of 1998 (iv) Mines and Mineral (Environment) (Exemption) (Amendment) Order, SI No. 31 of 2000 (v) Mines and Minerals Development (General) Regulations SI No. 84 of 2008 (vi) Mines and Minerals Development (Prospecting, Mining and Milling of Uranium ores and other Radioactive 
relevance to the soil sustainability discourse are the safety, health and environmental protection provisions under Sections 80 to 87 contained in Part VI of the MMDA. To start with, Section 4 provides for general principles applicable to the mining and development of minerals, among others:

Mineral resources are a non-renewable resource and shall be conserved, developed and used prudently, taking into account the needs of the present and future generations; mineral resources shall be explored and developed in a manner that promotes and contributes to socio-economic development and in accordance with international conventions to which Zambia is a party; the exploitation of minerals shall ensure safety, health and environmental protection; wasteful mining practices shall be avoided so as to promote sustainable development and prevent adverse environmental effects; citizens shall have equitable access to mineral resources and benefit from mineral resources development; and development of local communities in areas surrounding the mining area based on prioritization of community needs, health and safety.

These principles borrow heavily from international best practices on mining and the environment and are almost a replica of the provisions of the EMA. Overall, these principles are relevant for the protection of soil in mining areas and generally in Zambia. Section 6 establishes the Mining Licensing Committee which is tasked with considering applications for mining rights and non-mining rights and the grant, renewal or refusal of mining rights and non-mining rights in Zambia. The Committee is also responsible for terminating, suspending or cancelling mining rights and non-mining rights, amending terms and conditions of mining rights and non-mining rights; and advising the Minister on matters relating to its functions under MMDA. These outlined functions do not specifically point out that soil sustainability matters are at the fore of the conditions to consider before granting or varying a mining right. Given the nature of mining activities, however, it is argued that failure to implement measures aimed at securing soil sustainability must be explicitly stated as a condition for denying mining rights.

Section 12 prohibits exploration, mining and mineral processing without a licence or environmental impact assessment (EIA) granted by the Zambia Environmental Management Agency (ZEMA). Any person who contravenes this requirement commits an offence and is liable, upon conviction, to payment of a fine or imprisonment for a term not exceeding seven years, or to both. ${ }^{174}$ This provision is important for averting future environmental damage but cannot forestall historical contraventions that have yet to be remediated. Further sanction is provided for in Section 36 .

Production of mining may be suspended, or a mine closed where a mining rights holder fails to comply with the conditions of the mining right or mineral processing licence. Some of the omissions for which mining rights can be suspended or withdrawn include the creation of an unsafe environment or causing uncontrollable pollution from

Mineral Ores) Regulations, SI No. 85 of 2000 (vii) Mines and Minerals Development (Mining Rights and Non- Mining Rights) Order, SI No. 27 of 2009 (viii) Mines and Minerals Development (General) Regulations SI No. 7 of 2016.

174 Section 29(3) EMA, 2011. 
mining operations, among other reasons. It is clear that if such a provision is to be enforced, soil sustainability can be enhanced in mining and surrounding areas. Since the enactment of the MMDA, a number of mining companies have been held accountable for ongoing pollution, through court prosecutions. ${ }^{175}$

The provisions of Section 80 are also relevant in respect of soil sustainability as the Committee is mandated to take the following into account when granting mining rights:

The need to conserve and protect the air, water, soil, flora, fauna, fish, fisheries and scenic attractions; and the features of cultural, architectural, archaeological, historical or geological interests; and the need to ensure that any mining or mineral processing activity prevents any adverse socio-economic impact or harm to human health, in or on the land over which the right or licence is sought.

This provision is purposed to ensure that there is wholesome environmental well-being irrespective of the mining activities that are undertaken in area. This provision makes specific reference to soil conservation and protection as a consideration. Furthermore, this provision means that a mining licence will not be granted where the applicant is unable to show evidence of measures that will be taken to guarantee soil conservation and environmental protection.

Section 80 also makes provision that the Director of Mines Safety and the Zambia Environmental Management Agency ensure that applicants undertake all such environmental impact studies and other studies to be carried out as are considered necessary for ensuring that negative environmental impacts are mitigated in the interest of environmental protection. ${ }^{176}$

The MMDA empowers the Minister of Mines to propose additional conditions subject to which a mining right can be granted or renewed. ${ }^{177}$ The Minister is obliged to ensure that such conditions are prescribed in a statutory instrument and include:

the conservation and protection of (i) the air, water, soil, flora, fauna, fish, fisheries and scenic attractions; (ii) the features of cultural, architectural, archaeological, historical or geological interest; and (iii) in or on the land subject to the right or licence; (b) the protection of human health, in consultation with the Minister responsible for health; (c) the rehabilitation, levelling, regrassing, reforesting or contouring of such part of the land over which the right or licence has effect as may have been damaged or adversely affected by exploration operations, mining operations or mineral processing operations; and $(d)$ the filling in, sealing or fencing of excavations, shafts and tunnels.

A close examination of these conditions shows that these conditions are the same ones that the Committee is obliged to enforce under Section 80. The importance of enforcing these environmental conditions necessitates that the Minister is also given an opportunity to ensure that they have been adhered to at the time of granting the mining right.

175 Mulenga (2019: 3, 12-15).

176 Section 80(2).

177 Section 81(1). 
Section 81(2)(b) requires an applicant for a mining right to pay deposits of cash as may be prescribed, for the purpose of "securing the performance by that applicant or holder of a licence of all or any such conditions" as have been set. Some of the conditions may relate to soil conservation. In the event that the applicant does not fulfil those conditions, then the moneys paid are forfeited to the Environment Fund established under Section 86(1) discussed below.

Under Section 84, if a mining licence holder appears to be using wasteful mining practices, the Director of Mines or Director of Mines Safety is empowered to:

Give notice to the holder specifying the particulars of the wasteful mining practices; (b) request the holder to cease the wasteful mining practices and remedy any damage caused by the practices; (c) require the holder to reply, in writing, showing cause, within a time specified by the notice, why the holder's licence should not be revoked; and (d) suspend the mining operations until the holder takes remedial measures.

The MMDA does not define "wasteful mining practices" and there is no jurisprudence on this yet. It is, however, open to argument that such mining practices are obviously harmful to the environment. Given the proximity of mining activities to land and soil, it can be concluded that these are mining practices that are likely to contaminate soil and the environment in general. This legal provision is therefore progressive in sustaining soil health. In the event that the mining rights holder fails to remediate the environment, the Committee will cancel the licence. ${ }^{178}$ In addition, a mining holder is under legal duty to inform the Director of Mines Safety of any accident that occurs at a mining site, ${ }^{179}$ presumably to facilitate urgent remedial measures on the soil and immediate surroundings.

An Environmental Protection Fund is established in Section 86(1) administered and managed by the Environmental Protection Fund Committee appointed by the Minister. The funds in this Fund may be refunded to the holder in the event that there are no breaches of the conditions imposed in the mining right.

A holder of a mining right is "strictly liable" for any harm or damage caused by mining operations or mineral processing operations and must compensate any person to whom the harm or damage is caused. ${ }^{180}$ Further, Article $87(4)$ provides that where any harm or damage is caused to the environment or biological diversity, compensation must include the cost of reinstatement, rehabilitation or clean-up measures which are incurred and, where applicable, the costs of preventive measures. Liability extends to "any air, water or soil contamination or damage to biological diversity; or any other consequential disorder", among many others. ${ }^{181}$

178 Section 84(2).

179 Section 85.

180 Section 87(1).

181 Section 87(5)(e) and (g). 
The provisions of Section 87(1) introduce the notion of strict liability under the law of tort based on the rule in Rylands $v$ Fletcher. ${ }^{182}$ Strict liability ensures that the polluter, in this case, is liable independent of any wrongful intent or negligence. This is a progressive provision because mining is known to be a source of wide-ranging pollution, which ought to put holders of mining rights under a higher general duty of care to persons and the environment. Further, the monetary benefits that accrue from marketing minerals at international markets should be re-invested to mitigate negative environmental impacts.

Section 87(6) provides that, notwithstanding any other law to the contrary, the right to bring any action in respect of harm caused by mining or mineral processing operations should lapse after a reasonable period from the date on which the affected person or the community could reasonably be expected to have learned of the harm or damage. This provision is a marked departure from the position in Zambia where any personal injury cases must be litigated within three years. ${ }^{183}$ The section instead provides for a reasonable period within which to initiate litigation. The reasonableness of the period can be interpreted with reference to what environmental damage consists of. More specifically, if issues of soil contamination are at issue, scientific evidence would be required, and this would require long periods of time and processes to conclude. Section 87(6)(a) and (b) provide a guide on determining the reasonableness of the delay, namely consideration should be given to "the time the harm or damage may take to manifest itself and the time that it may take to correlate the harm with the mining or mineral processing operations, having regard to the situation or circumstance of the person or community affected."

Section 87(7) allows a "person, group of persons or a private or state organization" to bring a claim and seek redress in respect of the breach or threatened breach of any provision relating to damage to the environment, biological diversity, human and animal health or to socioeconomic conditions. According to this section, the cause of action may be brought in the interest of a person or group of persons; in the interest of or on behalf of, a person who is, for practical reasons, unable to institute such proceedings; in the interest of, or on behalf of, a group or class of persons whose interests are affected; in the public interest; and in the interest of protecting the environment or biological diversity.

Looking at these instances, the argument in favour of soil sustainability and the environment can be made by any interested party.

Further, legal costs must not be awarded against any of the persons specified under Section 87(7) who fail in any action if the action were instituted reasonably out of concern for the public interest or the interest of protecting human health, biological diversity and, in general, the environment. It is worth noting here that the provisions

183 Section 3(a) Law Reform (Limitation of Actions) Act, chapter 72 of the laws of Zambia. 
of Section 87(7) and 87(8), in particular, remove some legal barriers that hinder justice for the environment.

First, Section 87(7) addresses locus standi or 'the right to bring an action or to be heard' in a given forum. This provision has broadened the rule on locus standi by allowing any other party other than the affected person(s) to bring an action. In this regard, any interested person including environmental non-governmental organisations can bring an action in respect of breach or threatened breach of any provision relating to damage to environmental and biological diversity, human and animal health, and socioeconomic conditions. In light of this, this provision is a potent mechanism for advocating soil sustainability in mining areas in Zambia.

Secondly, Section $87(8)$ is also progressive because it provides that costs will not be awarded against any of the persons specified under Section 87(7) who do not succeed in an action instituted reasonably out of concern for the public interest or the interest of protecting human health, biological diversity and, in general, the environment.

While some of the provisions are quite unspecific, leaving room for interpretation, which could stand in the way of an effective implementation, the provisions of the MMDA, are - overall - progressive. In this vein, the provisions of the MMDA are likely to be effective in sustainable soil management and environmental protection, especially when read together with the provisions of the equally progressive, overarching Environmental Management Act. The enforcement provisions of both pieces of legislation are equally forward-looking. This said, it will be important to see how these laws will be utilised in the interests of the soil sustainability agenda and environmental protection, in the wake of the country's projected development trajectory.

\subsection{Agricultural legislation}

The projected development trajectory of the country rests on agriculture. It is expected that there will be further strain on agriculture in order to achieve the country's SDG targets. Despite this expectation, most of the sector legislation does not specifically address soil-related issues that have been pointed out as driving soil degradation. ${ }^{184}$ One reason for this is that the sector is still addressing one of its policy targets of reviewing its legislative and policy framework. Further, it is important to point out that the provisions of the Environmental Management Act (EMA), 2011 take precedence over other laws with regard to environmental matters. To this end, the shortcomings

184 These are the other pieces of sector legislation without clear relevance to sustainable soil management- The Cotton Act, chapter 227; Tobacco Act, chapter 237; Coffee Act, chapter 228; Plant Variety and Seeds Act; chapter 236; Plant Pests and Diseases Act, chapter 233; Food Reserve Act, chapter 225; Animal Health Act, 2010; Agricultural Institute of Zambia No. 2 of 2017; Agricultural Lands Act, chapter 187; Agricultural Credits Act No. 35 of 2010. 
of legislation in agriculture can be remedied by the EMA, 2011, where necessary. From the current legal framework, it is only possible to discuss two pieces of legislation.

\subsubsection{Fencing Act, Chapter 190}

The erection and maintenance of dividing fences is regulated by this piece of legislation. By implication, the Fencing Act may be relevant to soil sustainability in so far as environmental assessments may be necessary to undertake such developments.

\subsubsection{Agriculture (Fertilizers and Feed) Act, Chapter 226}

The preamble to the Agriculture Act provides that it is purposed to regulate and control the manufacture, processing, importation and sale of agricultural fertilizers and farm feed as well as provide for minimum standards of effectiveness and purity of such fertilizers and feed and other connected matters. The Act does not provide for standards relevant to soil quality or impact of fertilizers on the soil.

Public environmental legislation and soil sustainability

Public environmental law in the context of Zambia refers to the framework and sectoral natural resources legislation. These pieces of legislation are relevant in the quest for sustainable soil management. First and foremost, it is important to understand the Zambian land tenure system before focusing on the environmental and natural resources legislation. The discussion in the next section will be progress under the ambit of the relevant overarching constitutional provisions.

\subsubsection{Land tenure system}

The legal framework on land is governed by the Constitution and Acts of Parliament which are analysed in this section. From the constitutional perspective, Article 254 provides for classification and alienation of land and land tenure, which "land shall be delimited and classified as state land, customary land and such other classifications as provided." 185 The President, through the Lands Commission, is empowered to "alienate land to citizens and non- citizens for a prescribed tenure."186

Further, the Constitution makes provision for the protection from deprivation of property, which includes land. The relevant Article provides that: 
no property of any description shall be compulsorily taken possession of, and no interest in or right over property of any description shall be compulsorily acquired, unless by or under the authority of an Act of Parliament which provides for payment of adequate compensation for the property or interest or right to be taken possession of or acquired. ${ }^{187}$

The key point to note from this is that the land rights that are conferred on the strength of the constitutional right to property safeguard security of tenure, irrespective of whether the land is held under customary or state land tenure. By implication, soil sustainability is protected as an incidental benefit to land ownership.

The land tenure system in Zambia is generally acknowledged to be dualist in character and as a result, many issues arise with regard to land use and sustainability. The pre-colonial history of modernday Zambia was characterised by land being held on a usufructuary basis. This meant that individuals and families were connected to particular tracts of land for usage through their membership of communities. ${ }^{188}$ The right to claim land came with citizenship in a village, through registration in the village register. In essence, membership of the village could be given, or denied, by a headperson. This registration was carried out pursuant to the provisions of the Registration and Development of Villages Act, which is still in force and whose relevance to the soil sustainability discourse in Zambia has been discussed in relation to traditional authorities.

Customary tenure was largely influenced by social status and, as a result, security of tenure was a secondary consideration to social relationships rather than property rights. ${ }^{189}$ It has been argued that links to persons through whom land was acquired and by whom it could be used were crucial, and not the rights to land as such. The ability to control significant portions of land is closely associated with, and identified as an important source of, wealth, which becomes the subject of specific rights. ${ }^{190}$

Following the arrival of the British colonists, the Western concept of freehold land tenure and registration of individual property rights to Zambia was introduced. In 1911 the British South African Company (BSA Co.) was given royal authority to explore for minerals. ${ }^{191}$ The company thought that the declaration of a protectorate and a granting of land concessions were sufficient sources of title. ${ }^{192}$ The BSA Co. was authorised to apportion land to the indigenous people for their occupation. The indigenous people were not allowed to obtain title whereas the British settlers obtained land on either freehold or leasehold tenure. This has been attributed to the strong belief that, under African traditions, individuals did not own land. ${ }^{193}$

187 Article 16 of the Constitution of Zambia (as amended by Act No. 18 of 1996).

188 Loenen (1999: 5).

189 Mvunga (1980: 17).

190 Loenen (1999: 3-4).

191 Mvunga (1978: 54).

192 Loenen (1999: 9).

193 Mvunga (1980: 12). 
In 1924 the British Crown took over the administration of the Protectorate of Northern Rhodesia, now Zambia. The introduction of Crown land and Native Reserves by Council-in-Order in 1928 arguably clarified the uncertainty about which land was vested in the Crown, and that the occupation of Crown land was for the white settlers only. ${ }^{194}$ These lands were governed by statute, with tenure running for 999 years, while it was 99 years for agricultural land. ${ }^{195}$

Native Reserves were designated for the exclusive use of Africans and customary law applied to those areas. Further, non-natives were allowed to hold land in reserves for not more than five years. ${ }^{196}$ In 1947, the administration introduced Trust land in the law, out of Crown land and intended for the occupation of indigenous people. ${ }^{197}$ The difference between Trust Land and Native Reserves was the duration of a nonnative interest of 99 years in Trust Land. In Trust Land non-natives could be granted land if it was determined to be in the interest of both races. Alienation of land in Reserves and Trust Land required the consent of the native authority.

It has further been observed that the colonial government ensured that the most valuable land used primarily for farming and minerals was made available to settler farmers, and although a large proportion of those settlers left when Zambia gained its independence in 1964, most of the best farmland remained in the hands of the absentee landlord settlers. It should be noted that until 1970, the Western Province, formerly Barotseland, had a special status: it was the exclusive domain of the Lozi Litunga and his subjects. ${ }^{198}$ In 1970, an amendment to the Constitution of Zambia allowed uniformity in the land tenure system. Parts of the Western Province or Lozi area were formally ranked on a par with Reserves and Trust land elsewhere in the country. ${ }^{199}$

The country witnessed land reforms in 1975 through a new land policy which radically reviewed land tenure through the Land (Conversion of Titles) Act. Under these reforms, all land in Zambia became vested in the President, and freehold tenure was converted to statutory leasehold for a term of years not exceeding 100 years. Further, all vacant land was nationalised together with undeveloped plots, and the subdivision and sublease of land without the President's consent was prohibited. Furthermore, private ownership of land ceased to exist, and all land was declared to have no value. Since land had no more value, it ceased to be a saleable and mortgageable commodity. $^{200}$

In 1991 Zambia returned to multiparty politics and established a market-oriented government with corresponding economic policies which saw the need for a land

194 Mvunga (1978: 39).

195 Loenen (1999: 2).

196 Chinene et al. (1998: 9).

197 Mudenda (2007: 351-358).

198 Ibid.: 353.

199 Bull (2014: 27).

200 Mudenda (2007: 377). 
tenure reform to increase private sector development, and generate private and foreign investment. ${ }^{201}$ This led to the passage of the Lands Act 1995, which repealed the Land (Conversion of Titles) Act of 1975, the Zambia (State lands and Reserves) Orders, 1928 to 1964, the Zambia (Trust Land) Orders, 1947 to 1964 and other previous land laws. The Lands Act 1995 is the basis of the current land tenure system, although it is also fraught with numerous challenges. ${ }^{202}$

Leasehold tenure applies to state land and whatever pieces of customary land are on registered lease. There were about 200,000 leaseholds on 7 million hectares, about $9 \%$ of the country in $2016 .{ }^{203}$ There are four different types of state registered leases: first, a 10-year renewable Land Record Card issued on municipal land; secondly, a 14-year interim lease based on a sketch pending a registered boundary survey; thirdly, a 30year Land Occupancy License in municipal areas and settlement schemes; and fourthly, 10- and 30-year leases which the local authorities give without requirement for legally approved boundaries. A 99-year leasehold period is typical for all surveyed land. ${ }^{204}$

Approximately $40 \%$ of the country's population is on state land and it has been noted that this is a considerable proportion of the population to be on less than $10 \%$ of the country's available land. ${ }^{205}$ Customary land occupation accounts for a little less than $60 \%$ of the population, covering $90 \%$ of the country's area. Customary tenure is also home to the country's protected areas, wildlife estates, national parks, game management areas, and about $74 \%$ of protected forest areas. ${ }^{206}$

Public land in Zambia refers to those areas that are owned and taken care of by the government; it is simply all land that is neither private nor community land and is any other land declared to be public by an Act of Parliament. ${ }^{207}$ Common lands refer to grazing lands, grave sites, village woodlands, river frontages or any other classification reserved for community use by a group of people in a particular settlement area. The main Acts of Parliament relevant to land tenure in Zambia include those listed below.

\subsubsection{Lands Act, Chapter 184}

The Lands Act provides for the continuation of leaseholds and leasehold tenure and the continued vesting of land in the President and alienation of land by the President. The Act further provides for the statutory recognition and continuation of customary

201 Mudenda (2007: 405-407).

202 Loenen (1999: 7).

203 Ministry of Lands and Natural Resources (2017: 1).

204 Chinene et al. (1998: 4).

205 Ministry of National Development Planning (2006: 7).

206 Chinene et al. (1998: 7).

207 Sections 4(1) of the Lands Act. 
tenure, and conversion of customary tenure into leasehold tenure. The Lands Act, like the other pieces of legislation on land matters does not expressly make any reference to soil sustainability matters. As noted earlier, the legal and policy framework relating to land is earmarked for revision. It is hoped that the soil sustainability discourse can be incorporated into the ongoing consultations.

\subsubsection{Lands and Deeds Registry Act, Chapter 185}

The Lands and Deeds Registry Act provides for the registration of documents and the issuance of Provisional Certificates of Title and Certificates of Title, as well as the transfer and transmission of registered land.

\subsubsection{Land (Perpetual Succession) Act, Chapter 186}

The Land (Perpetual Succession) Act provides for perpetual succession to land and allows for the holding of land in trust as a body corporate.

\subsubsection{Land Survey Act, Chapter 188}

The Land Survey Act makes comprehensive provision for the registration and licensing of land surveyors, the manner in which land surveys should be carried out and diagrams and plans connected with land surveys should be prepared. The Act does not have any direct soil-relevant provisions.

\subsubsection{Lands Acquisition Act, Chapter 189}

The Lands Acquisition Act provides for the compulsory acquisition of land and other property. The Act ensures that adequate and prompt compensation is paid where it is liable to be paid or alternative land is provided as a replacement for the land compulsorily acquired. By implication, this piece of legislation might be relevant if the purpose for compulsory acquisition is about or related to soil conservation.

\subsubsection{Environmental Management Act, 2011}

The Environmental Management Act (EMA), 2011, is the framework environmental legislation in Zambia and makes innovative and progressive provisions in relation to 
the environment. ${ }^{208}$ This section analyses the provisions of the EMA through the sustainable soil management lens.

According to the preamble, the purpose of the EMA is to provide for "integrated environmental management" and the "protection and conservation of the environment and the sustainable management and use of natural resources". The EMA also provides for the preparation of the State of the Environment Report, environmental management strategies and other plans for environmental management and sustainable development. Further, the EMA is relevant for sustainable soil management in light of its provisions on the conduct of strategic environmental assessments of proposed policies, plans and programmes likely to have an impact on environmental management, prevention and control of pollution and environmental degradation. In an attempt to enhance environmental democracy in Zambia, the EMA also provides for public participation in environmental decision-making and access to environmental information.

The enforcement provisions of the EMA range from the establishment of the Environment Fund, which is yet to be operationalised, and environmental audit and monitoring, among others. One of the strongest features of the EMA is that it places national environmental protection in the context of international environmental agreements and conventions to which Zambia is a party, and which are critical in addressing land and soil degradation in particular.

In respect of all environmental matters, the provisions of the EMA, 2011, are only secondary to the Constitution. ${ }^{209}$ The EMA, 2011, has robust provisions for the protection of all aspects of the environment, including soil. ${ }^{210}$

Section 2 of the EMA, 2011, defines a number of terms that are used in legislation, two of which have direct relevance to soils. First, the term "element" in relation to the environment means "any of the principal constituent parts of the environment including water, atmosphere, soil, vegetation, climate, sound, odour, aesthetics, fish and wildlife". Secondly, "sustainable management" means the protection and management of the use of the environment, in a manner that, while enabling human beings to provide for their health, safety, social, cultural and economic well-being, (a) safeguards the life-supporting capacity of air, water, soil and ecosystems; and (b) maintains the life-supporting capacity and quality of air, water, soil and ecosystems, including living organisms, to enable future generations to meet their reasonably foreseeable needs. This explanation of terminologies underscores the importance of soil and ecosystems to the sustenance of all forms of life for the present and future generations.

The other references to soil in the EMA, 2011, are in Sections 75 and 76 of the EMA. Section 75 provides that the Zambia Environmental Management Agency

208 Sambo (2019: 651-654) offers an extensive review and analysis of the provisions of the EMA and whether or not it is succeeding in creating an 'environmental ethos' in Zambia.

209 Section 5.

210 Sambo (2019: 647-664). 
(ZEMA) should work in consultation with local authorities and other appropriate authorities, within five years of the commencement of the Act, which lapsed in 2016, to identify hilly areas at risk from environmental degradation. The EMA, 2011, further identifies hilly areas as at risk from environmental degradation by being prone to soil erosion, landslides occurring or being likely to occur, vegetation cover being removed or being likely to be removed from the area at a rate faster than it is being replaced; or any other land-use activity in that area being likely to lead to environmental degradation. The Minister of Environment is accordingly empowered to issue a list of landscapes and hilly areas that are regarded as being at risk from environmental degradation, and ZEMA must maintain a record of all these matters and devise strategies to ameliorate these soil-related problems.

The totality of the provisions under Section 75 of the EMA are very progressive and proactive. A search in the ZEMA registry, however, revealed that there is no record of such hilly areas that are at risk of environmental degradation, nor are there strategies devised to address the causes of such degradation. Further, ZEMA working in collaboration with the local authorities and the Minister responsible for the environment are supposed to facilitate public awareness of how to address the problem of environmental degradation. The EMA, 2011, creates a sound basis upon which the main drivers of land degradation in Zambia can be addressed, in the quest for general environmental well-being. It is, however, yet to be seen how these provisions will be implemented, especially in relation to soil governance. ${ }^{211}$

Section 76(1) of EMA, 2011, relates to the management of fisheries, water, forestry and wildlife resources, and provides that they will be managed in accordance with the provisions of the respective pieces of sectoral legislation. It can therefore be inferred that in relation to the protection of natural resources such as water, fish and other aquatic life, forests, and wildlife, due regard must be given to soil sustainability. Such provisions need to be clearly made in the legislation so that there is coordination in all policies and regulations that can foster soil sustainability in Zambia.

Section 105 is also relevant to sustainable soil management in Zambia in as far as it makes provision for the enforcement of environmental restoration orders. Here, if there is a discharge of a contaminant or pollutant into the environment in an amount, concentration or manner that constitutes a risk to human health or property, or that causes or has the potential to cause adverse effects, an environmental restoration order will be served to take any measures that will assist in reducing or eliminating the risk or harm and to take any measures to (a) take such action as will prevent the continuation or cause of pollution; and (b) restore land, including the replacement of soil, the replanting of trees and other flora and the restoration as far as may be, of outstanding geological, archaeological or historical features of the land or the area contiguous to the land.

211 Sambo (2019: 662-663). 


\subsubsection{Forests Act, No. 4 of 2015}

The Forests Act No. 4 of 2015 provides for the establishment and declaration of national forests, local forests, joint forest management areas, botanical reserves, private forests and community forests. It also provides for the participation of local communities, local authorities, traditional institutions, non-governmental organisations and other stakeholders in sustainable forest management. The Act also focuses on the implementation of the United Nations Framework Convention on Climate Change, the Convention on International Trade in Endangered Species of Wild Flora and Fauna, the Convention on Wetlands of International Importance, especially as Water Fowl Habitat, the Convention on Biological Diversity, the Convention to Combat Desertification in those Countries experiencing Serious Drought and/or Desertification, particularly in Africa, and any other relevant international agreements to which Zambia is a party.

The Forest Act is also a relatively new piece of legislation that has not yet aided the evolution of jurisprudence. It must however be noted that at the beginning of 2019, one important forest reserve in the regeneration of water resources in Lusaka district has been degazetted to pave the way for infrastructural developments. ${ }^{212}$ Given the importance of forest reserves in the sustenance of soil, ecosystems and the services they support, it is reasonable to conclude that the scientific perspectives that cause phenomena such as climate change are not well understood and assimilated into policy action. This is also evidence that there is no political buy-in in respect of natural resources management in Zambia.

Section 2 of the Act defines "forest produce" to include soil, among many other things, and also defines "forest resources" to include soil, in addition to vegetation, wood and non-wood products, and forest ecological services, including the maintenance of soil quality, control of erosion, provision of organic materials and modulating climate.

Section 45(1) empowers the Minister to issue, by statutory instrument, orders to the occupier of any land to undertake or adopt such measures necessary for the conservation of natural resources on land in an open area and the prevention of injury to natural resources by the acts or omissions of the occupier. An order issued pursuant to this section is known as a conservation order and may relate to:

(a) the allocation of the uses of land for arable, pasture, woodland or forest purposes or for water catchment; (b) the construction and maintenance of works for conserving water or soil and other works to preserve or improve natural resources; (c) the prohibition or restriction of cultivation of any part of the land; (d) the method of cultivation of land and the system of farming to be used on the land; (e) the manner of watering, managing, pasturing and moving livestock; (f) the preservation and protection of the source, course and banks of any stream; $(\mathrm{g})$ the control of water,

212 See https://tizambia.org.zm/transparency-international-zambias-statement-on-leaders-acquisition-of-land-on-forest-27/, accessed 2 February 2021. 
including storm water, drainage water and floods; (h) the prevention of pollution or fouling of public water as defined in the Water Resources Management Act, 2011; (i) the preservation of trees and other vegetation and the method and systems by which forest produce may be taken and used; (j) measures to prevent, control or combat fires, including the making of firebreaks and carrying out controlled burning.

The Act also provides for the implementation of several MEAs, which are specified in the preamble. This piece of legislation is relevant to soil sustainability, as shown in Section 45 where a conservation order may be enforced.

\subsubsection{Urban and Regional Planning Act, No. 3 of 2015}

The Urban and Regional Planning Act No. 3 of 2015 provides for development, planning and administration principles, standards and requirements for urban and regional planning processes and systems. It operates as a framework for administering and managing urban and regional planning in Zambia and establishes a democratic, accountable, transparent, participatory and inclusive regime for urban and regional planning. One important principle that is embedded in this legislation is broad-based participation of communities, private sector, interest groups and other stakeholders in the planning, implementation and operation of human settlement development. By implication, this should cover a multisectoral interest group which should also have a focus on soil sustainability because the geographical sensitivity of all areas is taken into consideration. This is not mentioned in the Urban and Regional Planning Act, which however, recognises the interconnected nature of issues that arise out of human settlements by making cross reference to other regulatory instruments such as the Environmental Management Act, the National Council for Construction Act, the Public Health Act, the Water Resources Management Act, and many others.

Not only does the Act establish procedures for integrated urban and regional planning in a devolved system of governance, but it also guarantees sustainable urban and rural development by promoting environmental, social and economic sustainability in development initiatives and controls at all levels of urban and regional planning. ${ }^{213}$ The Act further makes allowance for locational prerequisites for development, and the characteristics and diversity of particular areas are enhanced and protected. Ideally, the ability of particular soil types to withstand certain developmental processes should be taken into consideration as part of the environmental impact assessment (EIA) process. The question on whether soil sustainability is currently taken into consideration in the EIA process in Zambia is more specifically addressed in a later section of this chapter.

213 See http://www.daily-mail.co.zm/a-look-at-regional-and-urban-planning-act/, accessed 3 February 2021. 


\subsubsection{Local Government Act, No. 2 of 2019}

Section 16(2) of the Local Government Act outlines the functions of local authorities thus: 214

With respect to agriculture, a local authority shall (a) establish and maintain farms and allotment gardens; (b) take and cause the taking of measures for the - (i) storage, market and preservation of agricultural produce; (ii) conservation of natural resources; and (iii) prevention of soil erosion, including the prohibition and control of cultivation; (c) take and cause the taking of measures for the control of grass weeds and wild vegetation and for the suppression and control of plant and insect pests and diseases ... (Emphasis supplied).

This provision shows that local authorities, first and foremost, have responsibilities in environmental management as also outlined in the Constitution. Further, these responsibilities extend to conservation of natural resources and particularly to prevention of soil erosion. It however remains unclear whether the local authorities actually carry out these functions.

\subsubsection{Solid Waste Regulation and Management Act, No. 20 of 2018}

The Solid Waste Regulation and Management Act No. 20 of 2018 makes provision for the sustainable regulation and management of solid waste, general and self-service solid waste services, the regulation, operation, maintenance and construction of landfills and other disposal facilities and other related aspects. The Act does not apply to hazardous waste, e-waste, healthcare waste or waste regulated under the EMA, 2011. Section 5 outlines key concepts and principles in the management and regulation of solid waste, which are recognised as a resource. Some of the concepts and principles relevant to soil sustainability include the restriction of landfills and other disposal facilities near airdromes, wetlands, flood plains and ecologically sensitive areas. In addition, the Act prioritises the protection of the interests of consumers through effective participation of consumers in the management and decision-making processes for solid waste management.

Section 6(5) of the Act empowers local authorities to provide solid waste services in accordance with the Constitution. The functions of a local authority, with respect to solid waste, are described as "facilitating and managing activities that promote the key concepts and principles of solid waste management" as specified in Section 5 of the Act and "determining the location of landfills and other disposal facilities in accordance with international best practice, in consultation with the Zambia Environmental Management Agency". In carrying out the impact assessments that are mandatory in

214 First Schedule to the Local Government Act. 
the planning stages of the projects, soil management mechanisms need to be spelt out in order to ensure that there is no disturbance or pollution to the natural environment.

Sections 33 and 34 respectively prohibit the burning of solid waste other than in a prescribed manner and the burying of non-organic waste. The Act does not provide any explanation for this prohibition. However, in a similar vein to the unsustainable agricultural practice of 'slash and burn', unabated burning and burying of non-organic substances would inevitably lead to soil contamination, the environmental effects of which are far-reaching.

Section 78(2) on enforcement of the provisions of the Act provides that:

For the purposes of implementing and enforcing this Act, monitoring and containing the effects of solid waste on human health and the environment, an authorized person may enter on any land, with a warrant or with the consent of the owner or occupier, enter a private property or premise, after notifying the owner or occupier of the intention to do so; take samples of solid waste, soil and water for testing and analysis ...

This provision shows that soil evaluation is one of the main mechanisms for achieving the objectives of the Act, such as monitoring the effects of solid waste on human health and the environment. Given that the Solid Waste Regulation and Management Act is a relatively new enactment, it was not possible to ascertain whether the soil evaluations have actually been carried out pursuant to the provisions of Section 78(2).

5 Relevant policy framework on the main drivers of soil degradation

The legal and policy framework in Zambia does not directly address soil sustainability issues per se, but rather focuses on land tenure and usage systems, agriculture, forests, water and environmental protection generally. In examining the relevant legislation, particular focus is directed at the soil-relevant provisions, their enforceability and any applicable subsidiary legislation. This section starts by examining the policy framework in relation to the overall developmental agenda of the country. This is followed by a consideration of policies as they relate to the main drivers of soil degradation, namely land, environment, climate change, agriculture and mining, before examining the applicable legislative framework.

\section{$5.1 \quad$ Vision 2030}

Zambia's Vision 2030 (2006-2030) aims to transform Zambia into a prosperous middle-income nation by 2030 and to create a new Zambia which is a "strong and dynamic middle-income industrial nation that provides opportunities for improving the well- 
being of all, embodying values of socio-economic justice." 215 It comprises three priority sectors, namely economic growth and wealth creation; social investment and human development; and the creation of an enabling environment for sustainable social economic development.

Vision 2030 articulates long-term plans for development to achieve desirable socioeconomic outcomes by 2030 . The Vision is operationalised through five-year national development plans, the current being the Seventh National Development Plan (SNDP) for the period 2017 to 2021 . Implementation of Vision 2030 mandates the involvement of a variety of stakeholders including government, the private sector, cooperating partners, civil society, communities and individuals. Three-year mediumterm expenditure frameworks and annual budgets are also developed as part of the process.

Vision 2030 promotes a decentralised governance system and sets out specific goals and targets for different sectors, e.g., for the Energy sector, the target is to reduce the share of wood fuel to $40 \%$ by 2030 . This is one of the specific goals that is relevant for sustainable natural resources management, specifically for forests and soils.

Further, Vision 2030 recognises the abundance of land in Zambia, which is a necessary economic resource with potential to spur the country's growth. On one hand the abundance of the land resource is advantageous for enhancing a variety of developmental plans and, on the other, spells potential risk for soil protection. In achieving the development targets set in Vision 2030, it is important to ensure that environmental assessments are carried out and enforced in relation to protection of all-natural resources and soil in particular. It is envisioned that, by 2030, there will be access for all to good quality basic human necessities such as shelter and titled land. In the land sector, the Vision is to "secure fair and equitable access and control of land for sustainable socio-economic development by 2030". ${ }^{216}$

Zambia is currently implementing the Seventh National Development Plan (SNDP) which incorporates and localises the United Nations Sustainable Development Goals (SDGs) and Agenda 2063, which is the current model for $-^{217}$

transforming Africa into the global powerhouse of the future; the continent's strategic framework that aims to deliver on its goal for inclusive and sustainable development and is a concrete manifestation of the pan-African drive for unity, self-determination, freedom, progress and collective prosperity pursued under Pan-Africanism and African Renaissance.

Taken together, the SNDP and Agenda 2063 create and provide an entry point for further mainstreaming and road-mapping for the implementation of the United Nations SDGs in Zambia.

215 Ministry of National Development Planning (2006).

216 Ibid.: 33.

217 See https://au.int/en/agenda2063/overview, accessed 3 February 2021; Stevens (2019: 470 472). 


\subsection{Sustainable Development Goals}

The background to the 17 Sustainable Development Goals (SDGs) can be traced to the process leading to the 2012 United Nations Conference on Sustainable Development (UNCSD), whose outcome document The Future We Want, was used to negotiate and develop consensus on them. ${ }^{218}$ The set of 17 SDGs has 169 targets, many of which look quite similar to their predecessor, the Millennium Development Goals (MDGs), 2000-2015. ${ }^{219}$

The content of the SDGs spans environmental considerations such as land degradation, climate change and challenges such as the interrelated aspects of poverty and gender and other forms of marginalisation. It is this array of themes that links SDGs to sustainable soil management. Despite not being legally binding, the SDGs have since 2015 met global acceptance, and mechanisms of implementing them through national plans and strategies have been underway in Africa and the rest of the world.

Healthy soils and land resources are crucial to the achievement of the objectives and targets of many of the SDGs set out in Agenda 2030. More specifically, the SDGs relating to food security, water security/resources, climate change, biodiversity, and land management are directly related to securing global soil sustainability. ${ }^{220}$ Even though each of the SDGs can be summarised in terms of food, health, water, climate and ecosystems, the descriptions cover a wide variety of subtopics that require input by many different disciplines. For the purposes of this analysis, SDG 15 and its objective, Target 15.3 on land degradation neutrality (LDN) $)^{221}$ are the most relevant to sustainable soil management.

SDG 15 is targeted at protecting, restoring and promoting sustainable use of terrestrial ecosystems, sustainably managing forests, combatting desertification, halting and reversing land degradation and halting loss of biological diversity. Target 15.3 envisages that by 2030 desertification will have been combatted, and degraded land and soil restored, including land affected by desertification, drought and floods, and that the global community would strive to achieve a land degradation-neutral world. ${ }^{22}$

With these globally agreed targets, each country has devised plans and strategies on achieving land degradation neutrality, which is "a state whereby the amount and quality of land resources necessary to support ecosystem functions and services and enhance food security remain stable or increase within specified temporal and spatial

218 See https://bit.ly/2YWbJVj, accessed 3 February 2021.

219 Stevens \& Kanie (2016: 393-396).

220 Orr et al. (2017: 72-73).

221 For further reading on land degradation neutrality see: Metternicht et al. (2019: 189-191); Gilbey et al. (2019: 230-237); Von Malitz et al. (2019: 54-62).

222 See https://knowledge.unccd.int/knowledge-products-and-pillars/ldn-target-setting-buildingblocks/land-degradation-neutrality-ldn, accessed 3 February 2021. 
scales and ecosystems. ${ }^{" 223}$ This is against the background that the health and productivity of land globally is declining and, at the same time, demand for land resources is increasing. ${ }^{224}$

The problem of land degradation is particularly pronounced in Africa, and, for this reason, Zambia and other African countries need to utilise the opportunity given by SDGs and the concept of land degradation neutrality (LDN) to evaluate indigenous interventions. ${ }^{225}$ In terms of setting LDN targets, Zambia together with UNCCD and the International Union for Conservation of Nature (IUCN) has devised programmes engaging women farmers, project implementers, policymakers and NGOs with a view to mainstreaming gender in projects that support land degradation neutrality (LDN). ${ }^{226}$ There are presently no dedicated legal provisions that directly address the challenge of LDN except in so far as environmental well-being is concerned. It will therefore be important to ensure that the country targets for meeting LDN are given effect through specific and deliberate provision in relevant law and policy.

\subsection{Seventh National Development Plan}

The Seventh National Development Plan (SNDP) emphasises that Zambia's comparative advantage lies in its endowment of renewable and natural resources which can be productively harnessed. There is no concerted focus on the importance of soil sustainability, however. Further, the plan indicates that Zambia is competitive on tourism, greenhousing, and forestry and fishery sectors. The natural beauty makes tourism unique. The fact that Zambia is one of the most water-rich countries in Africa with a high intensity of sunshine opens new avenues for renewable energy generation. Lowcost greenhousing and construction have competitive edges because of the perfect soils for stabilised earth blocks. Forestry and fisheries, if sustainably managed, also have high potential. In addition to integrating development across key sectors for pro-poor economic growth, tackling vulnerabilities is poised to reduce social exclusion.

The plan further reveals that Zambia has to make fundamental policy shifts, particularly to food security and developmental projects, if the country is to achieve the objectives of Vision 2030. Actualising these shifts requires placing enormous pressure on the soil resource and there are no mitigatory factors alluded to in the plan.

According to the plan, accelerating economic diversification for shielding the economy from the effects of adverse commodity price fluctuations is cardinal. Progress

223 Orr et al. (2017: 15)

224 Smith (2018: 285-287).

225 Kibugi (2018: 387-390).

226 See https://www.unccd.int/news-events/ldn-projects-zambia-amplifying-gender-dimension, accessed 3 February 2021. 
towards diversification should show a much bigger reduction in the contribution of mining to the gross domestic product and increases in other sectors.

Lastly, the plan proposes building a strong manufacturing and industrial base, which is key to maintaining a strong export-oriented economy that can create resilience in the economy to both external and domestic shocks. This is crucial to ensuring a stable foreign exchange, enhanced foreign currency reserves, stable inflation, more decent jobs and an expanded capital base for the economy, among other things. A strong manufacturing and industrial base also help in forging backward and forward linkages between primary, secondary and tertiary industries and ensures sustained circular flow of resources within the economy, while bolstering job creation. The positive aspects of the national manufacturing and industrial base notwithstanding, it must be acknowledged that these sectors would pose contamination threats to the soil resources.

\subsection{Draft National Land Policy, 2017}

Primarily, land is the most important aspect that needs evaluation in order to understand its soil component. Regrettably, the National Land Policy (2017) is still in draft form. It has been subject of protracted discussions between stakeholders. ${ }^{227}$ The draft National Land Policy recognises that soil quality and fertility is declining, and measures need to be put in place to prohibit practices that contribute to this trend.

One of the major challenges in reaching consensus on the Draft National Land Policy is that the traditional leadership was of the general view that the proposals therein have the effect of usurping their authority over land administration in the country. ${ }^{228}$ For instance, one long-held observation is that the rights of landowners under customary law are undefined and sometimes contradictory. Further, there are no clear guidelines on the role and functions of traditional authorities and local authorities in the administration of customary land. Any attempts to resolve these matters which hinge on controlling the authority of traditional entities need to adopt a consultative and consensual approach; and the resultant decision would work in the interests of environmental sustainability.

\subsection{National Policy on Environment, 2009}

The National Policy on Environment identifies two main soil-relevant environmental challenges in Zambia, namely natural disaster risk and climate change effects. First,

227 The draft document is clearly marked as a working document and not a final policy, it should not be quoted and interpreted as government policy until finally agreed to and adopted.

228 Ministry of Lands and Natural Resources (2018: 1-3). 
Zambia is prone to extreme meteorological events such as droughts and floods, with major impacts on food security and public health. Climate change adds to existing environmental stress and is likely to affect Zambia's natural resource base negatively and exacerbate existing problems of land degradation, flood regulation, water purification, and droughts. Secondly, Zambia has been experiencing the effects of climate change resulting in extreme weather conditions, such as droughts, rising temperatures and unpredictable rainfall patterns. The frequency and intensity of climate events is expected to rise in future, with negative impacts on the economy and consequently people's livelihoods. ${ }^{229}$

It is estimated that the impact of climate change will cost Zambia approximately $0.4 \%$ of annual economic growth. It is further estimated that without action, rainfall variability alone could lead to losses of $0.9 \%$ of GDP growth over the next decade, thereby keeping a significant section of Zambia's population below the poverty line. ${ }^{230}$

In addition, the fall in the country's hydropower generation in recent times by about $600 \mathrm{MW}$ is mainly attributed to poor rainfall patterns. The lower supply of electricity has hampered growth prospects of Zambia's productive sectors of the economy, including agriculture, manufacturing, mining and services. Other adverse effects have led to increased costs of treating climate-related diseases such as malaria and the loss of natural environments, damage to infrastructure and disruption of biodiversity. Climate change adaptation and mitigation will, therefore, promote social well-being, including better health, growth of the economy and at the same time reduce environmental risks, such as shortage of water, air pollution and other effects. ${ }^{231}$

\subsection{National Climate Change Policy, 2016}

The long-awaited National Climate Change Policy (NCCP) for Zambia was finally launched in March 2017. It is aimed at addressing the impact of climate change and imminent reduction of the country's annual economic growth due to crop failure and the impact of climate change on energy production. The NCCP is long-awaited owing to the global urgency placed on individual countries to start initiatives aimed at fulfilling the objectives of the UNFCCC. The NCCP acknowledges that climate change has been widely recognised as one of the major challenges facing mankind at present, and Zambia is not exempt. ${ }^{232}$

229 Ministry of National Development Planning (2016: 2-8 and 34-36).

230 Zambia Country Climate Risk Assessment Report (2018) at https://www.climatelearningplatform.org/sites/default/files/resources/zambia_climate_risk_screening_report_-_final.pdf, accessed 3 February 2021.

231 Ministry of National Development Planning (2017: 54).

232 Ministry of National Development Planning (2016: 3). 
The NCCP is an important policy development that introduces a well-structured and coordinated national strategy to effectively tackle the adverse effects of climate change. Driven by the Ministry of National Development and Planning, it represents the much-needed broad-based consultative process involving all key stakeholders in Zambia. The NCCP recognises the need to ensure stronger collaboration among all ministries that have a role to play in climate change mitigation and adaptation, and special consideration of vulnerable groups such as poor rural women, children and the youth in Zambia.

One key feature of the NCCP is that it facilitates coherence between successive National Development Plans and all climate change programmes in the country. ${ }^{233}$ The multisectoral approach is an important ingredient for success in implementing projects and programmes because it is hinged on coordination through an established institutional framework. This is critical to achieving developmental goals through adaptation and mitigation interventions. The entire climate policy for Zambia is relevant to the soil sustainability discourse because the overall objective of the policy is to:

[p]rovide a framework for coordinating climate change programmes in order to ensure climate resilient and low carbon development pathways for sustainable development towards the attainment of Zambia's Vision 2030. ${ }^{234}$

Some of the specific objectives of the NCCP that are relevant to soil conservation include the promotion of implementation of sustainable land-use management practices in order to contribute toward reducing GHG emissions from land use and land-use change and forestry; and mainstreaming climate change into policies, plans and strategies at all levels in order to account for climate change risks and opportunities in decision-making and implementation. ${ }^{235}$

The NCCP lists the pieces of legislation that complement its implementation, notably, the EMA, 2011, and sectoral legislation such as the Forest, Wildlife, Lands, Agriculture, Energy, Mines and Minerals, Urban and Regional Planning, Water Resources and Fisheries Acts, which have been enacted and are currently in force. In addition, government is in the process of enacting new legislation, such as, more specifically, on climate change, in order to ensure effective implementation of the objectives and measures proposed in the NCCP. ${ }^{236}$

Some of the measures that have already been implemented, and are on course, include the provision of a framework for coordination of climate change programmes, ${ }^{237}$ enactment of climate change-specific legislation, promotion and strengthening implementation of adaptation and disaster risk-reduction measures to reduce vulnerability,

233 Ministry of National Development Planning (2016: 18-25).

234 Ibid.: 11.

235 Ibid.

236 Ibid.: 11-26.

237 Dupuy et al. (2019: 1). 
promotion of investments in climate resilient and low-carbon development pathways, and promotion and implementation of sustainable land-use management. ${ }^{238}$

Lastly, there are practical challenges in implementing the NCCP, which hinge on climate finance coordination. There is "no publicly accessible database containing a geo-located master list of all current and previously funded projects at either the national or sub-national level." There is also an absence of vulnerability assessment data, with international donors in some cases not utilising the coordinating centre in the Ministry of National Development Planning in the process of establishing and implementing climate-related projects and activities.

\subsection{National Agricultural Policy, 2016}

The First National Agricultural Policy 2004-2015 was established, based on the principles of liberalisation, commercialisation, linking the public and private sectors, and provision of effective services. The policy envisaged securing food supplies and developing an efficient, competitive and sustainable agricultural sector, able to contribute meaningfully to GDP, on the basis of five priority objectives, namely ensuring national and household food security; contributing to industrial development; increasing agricultural exports; generating income and employment opportunities; and maintaining and improving the agricultural resource base. ${ }^{239}$

In order to achieve these objectives, 19 strategies were devised. Some of the soilrelevant strategies included securing the quality, and sanitary and phytosanitary requirements of agricultural products for exports; strengthening agricultural services for small-scale farmers; arrangement of the institutional and legal framework; access to land, and pursuit of sustainable and environmentally sound agriculture.

The Second National Agricultural Policy (SNAP, 2016-2020) is being implemented at present. One of the priorities of SNAP is to ensure that the agricultural legislative framework is urgently overhauled. At the time of writing, none of the relevant pieces of legislation have been overhauled in line with this priority. As a result of failure to implement the important measure of legislative overhaul, SNAP seems not to have met most of its aspirations. It must however be noted that a number of positive initiatives have been undertaken in the agricultural sector, even in the absence of supporting legislation, such as conservation farming, which is relevant to sustainable soil management.

SNAP has 10 objectives and the formulation of four of these is directly relevant to soil sustainability, namely increasing agricultural production and productivity by promoting improved seed, efficient use of fertilizers and agrochemicals, efficient water

238 Personal communication with officers at the Disaster Management and Mitigation Unit.

239 Ministry of Agriculture and Cooperatives (2004: 1-4). 
resources usage and promotion of mechanisation in farming areas; ensuring the sustainable use and management of natural resources across the agricultural sector; improving food and nutrition security through the promotion and diversification of agricultural production and utilisation; and increasing private sector participation in agricultural development by strengthening the legal and regulatory framework which includes the formulation of new legislation.

The Second National Agricultural Policy, 2016-2020, is operationalised through the Ministry of Agriculture and local authorities. Among other objectives, SNAP promotes the sustainable management and use of natural resources through sustainable land management technologies such as conservation agriculture and appropriate stock densities. These measures are important for facilitating sustainable soil management. Some of the advantages of conservation farming that enhance sustainable soil management are that water infiltration and root development of plants are improved. ${ }^{240}$

Conservation farming also ensures the precise application of fertilizer and other inputs next to the plants where it is most likely to be beneficial to the plant and surrounding soils. Further, conservation farming is recommended by agricultural experts since it has the potential to restore soil fertility to land damaged by years of excessive ploughing and heavy applications of chemical fertilizer. Furthermore, conservation farming improves farm yields and incomes with moderate input, whereas conventional hand-hoe technologies that are steadily being replaced, are responsible for unnecessary soil removal. ${ }^{241}$

Zambia is involved in diverse initiatives and commitments at both regional and global levels. These initiatives and commitments operate in the realm of international law. State parties to international treaties must enter into the obligations created with a view to maintaining them.

With the exception of customary international law, Zambia follows the doctrine of dualism where international instruments are not self-executing. ${ }^{242}$ Accordingly, the Executive wing of government does not have law-making powers in this context. The law-making function is vested in the Legislature. ${ }^{243}$ Further, an examination of Article 7 of the Constitution, which outlines the sources of law in Zambia, shows that international law is not included. This is because international agreements and treaties, as

240 Shitumbanuma et al. (undated).

241 See http://www.fao.org/conservation-agriculture/en/, accessed 3 February 2021.

242 Munalula (2004: 89-90).

243 Article 62(2) and (3). 
sources of international law, are subject to National Assembly approval and domestication into national statutes.

The constitutional process for negotiating and signing international commitments is an Executive function of the President, subject to National Assembly oversight, as outlined in Article 92(2)(c) of the Constitution. Further, in accordance with Articles 63 and 114(1)(d), Cabinet may recommend the accession and ratification of international agreements to the National Assembly.

In order to streamline implementation of these constitutional provisions and facilitate the domestication of international commitments, the Ratification of International Agreements Act, No. 34 of 2016, was enacted. Section 3(1) of this Act provides that whenever the question of ratification of an international agreement arises, the Minister responsible for the subject matter of the international agreement must undertake a due diligence exercise and consider whether it would be in the "best interests of the State to ratify the international agreement". The due diligence exercise essentially requires of the proposing Ministry to make a case for the subject matter of the international agreement. Thereafter, such a report is presented to Cabinet and subsequently to the National Assembly.

Article 12(1) provides that where the National Assembly approves the ratification of an international agreement, the responsible Ministry must, where necessary, initiate the domestication process. The domestication process may involve a number of processes which may include the enactment of local legislation that sets out the international agreement in a schedule; setting out salient provisions of the international agreement, in the substantive part of an Act, that will require specific interventions or measures to be undertaken, and annexing the international agreement to the Act; rephrasing the terms of the international agreement in an Act and annexing the agreement to the Act; adopting, in an Act, the terms of the international agreement in its entirety; or the use of any other enforceable means, where applicable.

In relation to international environmental agreements that undoubtedly also incorporate soil sustainability mechanisms, the provisions of the EMA, 2011, are more apt. Section 84 of the EMA provides that the government will exercise and give effect to Zambia's sovereignty over its environment and natural resources, including its genetic resources, and its powers and rights to manage the living and non-living natural resources within its territories and in areas over which it exercises rights of sovereignty, to the fullest extent permitted under international law.

Further, the EMA provides that government will cooperate with other governments, and with local and international organisations in order to protect the regional and global environment. The Minister will, after signing an international agreement designed to protect the environment, as soon as is practicable: (a) cause the agreement to be ratified; and (b) take appropriate measures to give effect to the agreement. The Minister may delegate to ZEMA, an appropriate authority, a conservancy authority or 
other relevant institution, the implementation of any international agreement relating to the environment to which Zambia is a party.

Against this legal background, any international obligations that are relevant to sustainable soil management in Zambia may be considered for implementation as national legislation, subject to completion of the processes outlined in the Constitution, the EMA and the Ratification of International Agreements Act. The following section analyses some of the international obligations which are applicable in Zambia, subject to domestication.

\subsection{Regional commitments}

At subregional level (i.e., SADC), Zambia is signatory to agreements and protocols on forests, wildlife, water, energy, agriculture, and others that fall under trade through COMESA. Some of these are relevant to soil sustainability and are analysed below.

\subsubsection{Common Market for Eastern and Southern Africa}

The Common Market for Eastern and Southern Africa (COMESA) is an organisation of free independent sovereign states, including Zambia which have agreed to cooperate in developing their natural and human resources for the good of all their people. ${ }^{244}$ The primary objective of the COMESA Treaty is to enhance trade and economic cooperation amongst the state parties. The COMESA state parties have, however, committed themselves to specific undertakings in order to achieve their organisational objectives. Of relevance to the soil sustainability discourse are undertakings in respect of the fields of agriculture and economic and social development.

In relation to agriculture, each state party undertakes to cooperate in agricultural development, adoption of a common agricultural policy, regional food sufficiency, enhancement of rural development, and cooperation in agricultural research and extension. ${ }^{245}$ All of these undertakings primarily depend on soil sustainability because soil is the basis of agricultural production and food security. The economic and social development undertaking mainly envisages cooperation in the development and management of natural resources, energy and environment. ${ }^{246}$ This undertaking is the umbrella commitment to ensure natural resource conservation and sustainability, and ultimately environmental well-being. It must be re-emphasised at this juncture that soil is the nexus of all life-giving necessities such as water, food and opportunities.

244 See https://www.comesa.int/comesa-treaty/, accessed 3 February 2021.

245 Article 4(1)(5)(a) to (g) of the COMESA Treaty.

246 Article 4(1)(6)(h) of the COMESA Treaty. 
One observation to make about the cooperation and integration in COMESA with regard to soil sustainability is that there is no deliberate focus and attention drawn to soil health. There are however many opportunities that can be exploited to realise soil sustainability within and beyond the geographical parameters of the member states of COMESA. The framework for regional cooperation and integration has already been established and the COMESA Treaty has provisions that can be interpreted to mean that the windows of cooperation are not closed in respect of other relevant aspects that are likely to enhance the economic and social development of the member states. Further, in the event that these windows of opportunity are open for advancement of the soil sustainability discourse, the question of effective enforcement of the ensuing commitments would arise. Implementation and enforcement issues would range from economic, political and institutional constraints, as are common in most economic integration treaties. ${ }^{247}$ In this context, one problem would be that soil sustainability may not be viewed as a very direct priority towards enhancing trade.

\subsubsection{Southern African Development Community}

The Southern African Development Community (SADC) is a regional economic community of which the Republic of Zambia is a member. The objectives of SADC include the promotion of sustainable and equitable economic growth and socioeconomic development as a way of alleviating poverty through regional integration. ${ }^{248}$ Additionally, the sustainable utilisation of natural resources and effective protection of the environment are among the other main objectives of SADC. ${ }^{249}$ At this point, it is noteworthy that there is no dedicated focus on soil sustainability in the SADC objectives. It must however be mentioned that "effective protection of the environment" can be interpreted to mean that. In achieving its objectives, SADC gives priority to improved utilisation and stewardship of natural resources, by focusing on key areas, namely forests, wildlife, fisheries, trans-frontier conservation areas, and water. ${ }^{250}$

\subsubsection{African Union}

The African Union (AU) launched in 2002 as a successor to the Organisation of African Unity (OAU, 1963-1999), is a 55-member state continental body. ${ }^{251}$ Zambia is among the 55- member states of the AU, which was established with a view to

247 Geda \& Kebret (2008: 357-360).

248 Zongwe (2011: 12).

249 Article 5(1)(a) and (g) of the SADC Treaty.

250 Zongwe (2011: 17).

251 See https://au.int/en/overview, accessed 3 February 2021. 
accelerating the process of integration on the continent to enable Africa to play its rightful role in the global economy, while addressing multifaceted social, economic and political problems compounded by certain negative aspects of globalisation. This was a build-up on the OAU Pan-Africanism which centred around African socialism and promoted African unity, the communal characteristic and practices of African communities, and a drive to embrace Africa's culture and common heritage.

Some of the objectives of the AU that are directly relevant to sustainable soil management in Zambia and Africa generally include promoting sustainable development at the economic, social and cultural levels, as well as the integration of African economies; promoting cooperation in all fields of human activity to raise the living standards of African peoples; advancing the development of the continent by promoting research in all fields, in particular in science and technology; and promoting and defending Africa's common positions on issues of interest to the continent and its peoples. ${ }^{252}$

Given this basis for cooperation in respect of these objectives, notably promotion of sustainable development, it is clear that African states are of one mind regarding advancing the needs of the continent such as natural resources conservation and environmental sustainability.

In order to achieve its aspirations, the AU has a continental strategic framework, Agenda 2063 that aims to deliver the goal for inclusive and sustainable development in Africa. ${ }^{253}$ It is interesting to note that at this juncture, African states are required to implement both Agenda 2063 as part of AU commitment and Vision 2030 in response to global international law. Agenda 2063 and the 2030 Agenda have a broad nexus on social development (people), on inclusive economic development (prosperity), on peaceful and inclusive societies and responsive institutions (peace), and on a number of environmental sustainability issues (planet). ${ }^{254}$ This creates a foundation for implementing both initiatives in African countries without compromising the achievement of sustainable development. Against this background, there is an opportunity for African countries to cooperate towards introducing and sustaining the soil conservation agenda.

\subsection{Multilateral environmental treaties}

Zambia has either ratified or signed the conventions listed in this section which are generally and specifically relevant to enhancing soil sustainability both in Zambia and

252 See https://au.int/en/overview, accessed 3 February 2021.

253 See https://www.un.org/en/africa/osaa/pdf/au/agenda2063-presentation.pdf, accessed 3 February 2021.

254 See https://bit.ly/3txZPip, accessed 3 February 2021. 
internationally. Some pieces of legislation in Zambia, like the environmental framework legislation EMA, 2011, and others such as those relating to water, fisheries, forests and wildlife, to name but a few, have provisions for implementing some of these multilateral environmental agreements (MEAs). This section specifies the provisions of the various pieces of legislation that implement the MEAs under discussion.

The Convention on Biological Diversity (CBD) came into force in 1993. Its objective is to conserve biological diversity as a way of achieving sustainable development. Some of the strategies in place to achieve this are to decrease the rate of loss of natural habitats, to establish conservation areas, to restore degraded areas and to protect environments susceptible to human impacts.

The United Nations Convention to Combat Desertification (UNCCD) was established in 1994 with the objective of improving the living conditions of vulnerable populations living in arid, semi-arid and dry subhumid areas.

The Convention on International Trade in Endangered Species of Wild Fauna and Flora (CITES) entered into force in 1975 and is aimed at ensuring that the international trade of specimens (fauna and flora) does not threaten their survival.

The Ramsar Convention on Wetlands of National Importance especially as Waterfowl Habitat, adopted in 1971, was established for international cooperation and national action to protect wetlands and their resources.

The United Nations Framework Convention on Climate Change (UNFCCC) was negotiated under the auspices of the United Nations in 1992, upon global recognition of the need to limit human activities which contribute to climate change and to negotiate immediate measures for addressing climate change together with its negative effects. The overall objective of the UNFCCC is "stabilization of greenhouse gas concentrations in the atmosphere at a level that would prevent dangerous anthropogenic interference with the climate system". 255

Others include the Montreal Protocol on Substances that Deplete the Ozone Layer; the Vienna Convention on the Protection of the Ozone Layer; the Basel Convention; the Bamako Convention; the Rotterdam Convention; and the Stockholm Convention. From the international legal framework, it must be noted that there is no single convention that is dedicated to soil sustainability matters, although most of them have provisions that can be adapted to do so.

This section analyses cross-cutting issues that have an impact on the achievement of soil sustainability in Zambia. 


\subsection{Environmental impact assessments}

The EMA, 2011, makes provision for environmental impact assessments (EIAs) as systematic examinations which must be conducted to determine whether or not an activity or a project has or will have any adverse effects on the environment. Section 117 of the EMA provides that a person who:

wilfully fails to undertake an environmental impact assessment contrary to the provisions of this Act; fails to prepare and submit a project brief or an environmental impact assessment report as required under this Act; or recklessly or fraudulently makes a false statement on an environmental impact assessment report submitted under this Act; commits an offence and is liable, upon conviction, to a fine not exceeding seven hundred thousand penalty units or to imprisonment for a period not exceeding seven years, or to both.

In a nutshell, the provisions of Section 117 mean that the conduct of EIAs before undertaking any activity as prescribed under the EMA, 2011, is mandatory, the breach of which renders one to be criminally liable, as prescribed. EIA regulations exist under the EMA, 2011, in order to support the enforcement of the provisions of the principal legislation. ${ }^{256}$ The applicable 1997 EIA regulations were issued pursuant to the repealed Environmental Protection and Pollution Control Act (EPPCA), 1999.

From a strictly environmental rationale, these regulations should not be in force, having been technically repealed together with the outdated parent legislation in 2011. This is because the EPPCA, 1990, was repealed on account of the fact that it no longer represented the aspirations of present-day environmental discourse. On technical legalities, the regulations have force of law on the basis that where any Act of Parliament is repealed, any statutory instrument issued thereunder remains in force as long as it is not inconsistent with the repealing written law. ${ }^{257}$ As the current regulations have not yet been challenged for being inconsistent with the aspirations of the EMA, 2001, they remain in force for the time being.

The Environmental Protection and Pollution Control (EIA) Regulations, 1997, are relevant to sustainable soil management in Zambia because they make provision to consider soil fertility as a possible adverse environmental effect. Regulation 8(3) refers to ecological considerations which must be taken into consideration when effecting development activities as follows:

(a) Biological diversity such as effect on number, diversity, breeding sites, etc. of flora and fauna, breeding populations of fish and game; and effects on the gene pools of domesticated and wild sustainable yield.

(b) Sustainable use including the effects on soil fertility, nutrient cycles, aquifer recharge, water run-off rates, aerial extent of habitats; and bio-geographical processes.

256 Statutory Instrument No. 28 of 1997, the Environmental Protection and Pollution Control (Environmental Impact Assessment) Regulations, 1997.

257 Section 15, Interpretation and General Provisions Act, chapter 2 of the Laws of Zambia. 
This provision shows that EIAs are purposed to protect the totality of biological diversity and ensure sustainability. It has been noted in the earlier discussions that soil is important to the ecosystem-balance equation. The provisions of regulation 8(3) outline the components of ecosystems that need to be protected. The regulations, however, underestimate the value of soils by only considering their fertility, and not necessarily their sustainability. As pointed out, these regulations were made pursuant to a repealed piece of legislation, which was repealed to pave the way for the enactment of a more forward-looking framework legislation. Indeed, there is evidence that the EMA, 2011, is forward-looking and encompasses current global trends in environmental well-being.

Against this background, the 1997 regulations must be immediately replaced by more robust and modern provisions, which can be used to anchor the sustainable soil management campaign in Zambia.

\subsection{Public participation}

Public participation in environmental decision-making in Zambia is provided for under the constitutional provisions, read together with those in the EMA, the Water Resources Act and almost all the natural resource legislation enacted after 2011. ${ }^{258}$ This section analyses the public participation provisions of the Constitution and the EMA.

Article 255(1) of the Constitution makes provision for principles of environmental and natural resources management and development while Article 257(d) refers to modalities for utilisation of natural resources and management of environment. Both Article 255(1) and 257(d) refer to public participation as an important consideration in the management and utilisation of natural resources and can both be interpreted with soil sustainability in mind. The Constitution, however, does not define what amounts to 'public participation' in the management of the environment. This constitutional provision is amplified by the provisions of the environmental framework legislation, EMA, which is discussed below.

Sections 91-94 of the EMA make provision for public participation in all environmental matters. This includes the use and management of soil as a natural resource. To start with, Section 91 provides that the public has the right to be informed of the intention of public authorities to make decisions affecting the environment and of available opportunities to participate in such decisions. The public has the right to participate in decisions concerning the formulation of environmental policies, strategies, plans and programmes and to participate in the preparation of laws and regulations relating to the environment. ${ }^{259}$ 
Section 91(3) mandates ZEMA and any other appropriate authorities to establish mechanisms for collecting and responding to public comments, concerns and questions relating to the environment, including public debates and hearings. This provision is relevant in understanding the measures that are in place for soil sustainability in Zambia. Further, the general public is entitled to review documents relating to environmental well-being and conduct public hearings on any document under public review. ${ }^{260}$ This innovation has been implemented but it is not accessible to members of the general public as there is no publicity about it. Further, the use of such an innovation must be understood against the backdrop of low awareness levels about environmental matters in Zambia. ${ }^{261}$

\subsection{Access to information}

The EMA has innovative provisions on access to environmental information, which is relevant for sustainable soil management in Zambia, although no specific reference is made to the concept. Sections 86-90 of the EMA are the relevant provisions in relation to environmental information. Section 86 of the EMA is worth reproducing in full; it provides that ZEMA will gather information on the environment and natural resources; subject to any other written law, have access to any data collected on the environment and natural resources; analyse information relating to the environment and natural resources; disseminate information to public and private users; commission studies in demography and trends impacting on environmental and development issues; carry out public information and education campaigns in the field of environment; exchange information relating to the environment with non-governmental organisations and any other regional and international organisations; co-ordinate the management of environmental information with sector ministries; advise the Minister on existing information gaps and needs; and establish, in consultation with sector ministries, guidelines and principles for the gathering, processing and dissemination of environmental information.

The duty placed on ZEMA in this provision means that environmental information of a wide- ranging ambit must be made accessible to the public. For instance, if members of the public wish to access and review any information or data on soil and related matters, ZEMA should oblige. Further, Section 86(2) mandates the Director-General of ZEMA to publish "any information on the protection, conservation, management and utilization of the environment and natural resources as the Director-General considers necessary for public education and awareness". This is an especially important provision, which if well utilised could be the entry point, in addition to many other 
provisions, for a dedicated focus on soil sustainability as it promotes general environmental well-being.

Section 87 provides that ZEMA "shall establish and operate a Central Environmental Information System in which shall be stored any findings, data and statistics generated by both public and private bodies in the course of environmental observation and management." This is another progressive provision that can be relied on in making an argument for information on soil protection to be centrally managed and utilised in conjunction with other agencies.

Section 88 empowers the Director-General of ZEMA, in consultation with the relevant appropriate authorities, to take measures for the integration of environment matters in schools, colleges and institutions of higher learning. Further, the EMA places a duty on the Director- General of ZEMA to "plan and conduct programmes aimed at raising awareness of the public on sustainable development and environmental management". This section can also be used to ensure that there is wide publicity and awareness on soil matters as they relate to environmental protection and sustainable development.

Under Section 89, ZEMA is mandated to conduct surveys on the state of the environment, to conduct research, to forecast environmental changes, and to undertake other studies that may contribute to the formulation of policies and preparation of action plans and strategies with regard to environmental protection, conservation and management. This is important for soil management because it is a multi-sectoral subject that requires concerted efforts and coordination of many players. Notwithstanding the provisions of section 89, the Minister responsible for the environment may designate any institution as an advisory body charged with the responsibility of enhancing of targeted scientific research, and information generation in the field of environment and the monitoring and assessment of effectiveness of actions taken.

Section 90 mandates ZEMA to create and maintain an environmental information registry which contains information relating to the environment, including a list of the Acts of Parliament, statutory instruments, international environmental agreements to which Zambia is a party, and any policies, plans, guidelines, studies, reports, decisions, recommendations and other publications relating to the environment published by ZEMA, the Minister or the government; a list of every environmental management strategy and environmental management strategy review report issued by any Ministry; every State of the Environment Report and every National Environmental Action Plan; every National Waste Management Strategy; a list of each application for a licence or approval under the EMA; a list of each licence, order and approval issued under the EMA; and details of all charges laid and convictions entered for contravention of the EMA.

Further, ZEMA is expected to keep all these documents in the form of paper documents, in one location, copies and information documents of the matters listed in the registry which must be accessible for public viewing during ordinary business hours. 
The mandatory wording of the relevant sections on environmental information in the EMA show that this is an important matter that the general public must utilise in the quest for sustainable environmental management. There is no jurisprudence at the moment to show how this provision has been implemented, save that records at the ZEMA offices show that there is minimal use of the environmental information registry by local communities.

The current legal and institutional framework concerning foreign investors in Zambia comprises the Constitution, applicable sectoral and tax legislation, the Zambia Development Agency Act, Companies and Business Regulatory Acts, and all other allied policies and institutions created thereunder. ${ }^{262}$ Research was conducted between 2013 and 2015 to understand how strengthening law and policy frameworks and the regulatory and governance capacity of officials and civil society could enable Zambia to manage investments, so that they contribute to sustainable development outcomes. It was found that such investments were on the increase in Zambia. There were both foreign and domestic private investors contributing to the Zambian economy, which is heavily reliant on land use and natural resource capital. ${ }^{263}$ Most of the targeted investment opportunities in Zambia are in key economic sectors, namely energy, forestry, mining and agriculture. As these sectors are land- and soil-related, it is critical to enhance the sustainability measures that are in place.

It is acknowledged that "land-use investments can activate development and boost the economy by creating direct benefits such as local employment and infrastructure", ${ }^{264}$ however, economic, social and environmental inequities can arise from investments, including breach of property rights, unsustainable land use and environmental degradation and labour rights abuses, among others.

There are inadequate regulatory frameworks and weaknesses in the rule of law which have allowed investors and the Zambian 'elite' to circumvent legal requirements. ${ }^{265}$ Four major challenges can be mentioned, which are common to all four key sectors, which limit the capacity of the country to attract and regulate sustainable investments: There are very few incentives that support sustainable land-use investments; customary land tenure remains insecure, with limited processes enshrined in the legal framework to uphold social safeguards, such as consultation with land users; there is low institutional capacity to enforce the social and environmental

262 Sambo et al. (2015: 7-9).

263 Ibid.: $1,10$.

264 Ibid.: $2-3$.

265 Ibid.: $10-54$. 
safeguards that are established in the law; and access to information on investments is limited in Zambia, which reduces the potential for public scrutiny and participation. ${ }^{266}$ The research concluded that the legal and institutional framework on Zambia, particularly its implementation and enforcement, should be strengthened. This will lead to more effective regulation of sustainable investments that adhere to social and environmental safeguards. The ultimate success of adopting these recommendations would be seen in the strides that would be made towards achieving the SDGs.

The enforcement of laws generally in Zambia has not been without administrative and other challenges. In many country reports on access to justice, it has been noted generally that inadequacy of expertise in specialised legal areas and inadequate staffing levels have continued to hamper competence of enforcement. With specific reference to enforcement of environmental matters, and soil sustainability in particular, the EMA makes provision for the establishment of the Environmental Fund as well as several other enforcement mechanisms, discussed below.

\subsection{The Environment Fund}

According to Section 95, the Environment Fund consists of such moneys as Parliament may appropriate for its purpose; voluntary contributions to the Fund from any person or organisation; such sums as may be levied from, or donated by, a person, industry or developer conducting an activity which has, or is likely to have, an adverse effect on the environment; any grants mobilised from any source, within or outside Zambia, for the purpose of environmental management and protection; and other sources. It is noted here that a provision exists for accumulating levies collected from any developer conducting activities that have, or are likely to have, an adverse environmental impact. Of relevance to this report, are activities that have a negative impact on soil sustainability. Section 95(3) provides that the Environment Fund established pursuant to the EMA does not apply to industries, facilities and activities covered by the Environmental Protection Fund established under the Mines and Minerals Development Act, 2015, and the Petroleum (Exploration and Production) Act, 2008, which have other guidelines, as discussed under the respective sectoral sections in this report.

The Environment Fund, as part of the enforcement mechanisms of the frame environmental law, the EMA, is purposed for: 
[m]itigating or restoring environmental degradation and adverse effects on the environment; facilitating research to further the requirements of environmental management and sustainable natural resource management; and such other purpose as may be prescribed. ${ }^{267}$

The management and administration of the Environment Fund is vested in ZEMA. Under Section 98, ZEMA is mandated to create a register of the activities, industrial facilities and plants, undertakings and businesses which have, or are likely to have, adverse effects on the environment when operated in a manner that is not in conformity with good environmental practices.

The other environmental enforcement provisions in the EMA relate to audits, monitoring, prevention orders, protection orders, restoration orders, compliance orders, cost orders and prosecution, which can be either civil or criminal. These enforcement mechanisms are now analysed in the context of soil sustainability.

\subsection{Environmental audits}

Section 101(1) provides that "an owner of premises or a person undertaking a project shall take all reasonable measures to mitigate any adverse effects not contemplated in the environmental impact assessment" in respect of their premises or the project, and "shall prepare and submit an environmental audit report on the measures to ZEMA annually or as ZEMA may, in writing, require." The section also mandates ZEMA to carry out an environmental audit of all the activities that are likely to have an adverse effect on the environment. This provision of the EMA can be used to enhance soil protection. It is arguable that, in a number of instances, soil conservation may be overlooked as an important consideration in EIAs for development projects. This provision therefore allows for soil sustainability issues to be incorporated for consideration after the inception of the project.

In order to enhance enforcement, ZEMA inspectors may enter any land or premises for the purpose of determining the extent to which the activities carried out on the land or premises conform with the environmental impact assessment made in respect of the land or premises. This enforcement mechanism can be applied to all development projects that have since commenced but did not initially take negative impacts on soil sustainability into account. Any owner of premises or person undertaking a project for which an environmental impact assessment is conducted must keep accurate records and make annual reports to ZEMA, describing the extent to which the project conforms, in operation, to the environmental impact assessment. Suffice it to mention that this is yet another opportunity that can be used to report adverse impacts on soil sustainability and remediation effected. 


\subsection{Environmental monitoring}

Section 102(1) empowers ZEMA, in consultation with other relevant agencies or bodies, to monitor:

[a]1l environmental phenomena with a view to making assessments of any possible changes in the environment and their possible impacts; or the operation of any industry, project or activity with a view of determining its immediate and long-term effects on the environment.

This provision means that environmental monitoring can be extended to "any possible changes in the environment" which include changes in soil composition, fertility and sustainability. This enforcement mechanism can be used to ensure that soil matters are also given priority as they contribute towards sustaining a clean and healthy environment. Further, ZEMA inspectors may enter any land or premises for the purposes of monitoring the effects upon the environment of any activities carried out on that land or premises.

\section{$9.4 \quad$ Prevention orders}

Section 103(1) provides that where the Director-General has "reasonable grounds to believe that a person is, or will be, conducting an activity, or is or will be in possession or control of a substance or thing that may result in an adverse effect", the DirectorGeneral may serve a prevention order on that person. Section 103(2) further provides that a prevention order served on a person under subsection (1) may require that person to:

[p]repare a written emergency response plan to reduce or eliminate the risk and provide a copy of the plan to the Director-General; have any necessary equipment, facilities and trained personnel available to deal with the risk; upon an identified event or set of circumstances occurring, implement the plan; and take measures that are necessary to ensure that any emergency can be effectively dealt with.

Any person served with a prevention order must comply with its requirements by the date or dates specified in the order and, if no date is specified, the person must comply with the order immediately. ${ }^{268}$ Failure to comply with this provision renders one liable, upon conviction, to a fine and/or imprisonment, or both. ${ }^{269}$ There is currently no available jurisprudence on this legal provision. In severe breaches of soil management, it is arguable that these legal sanctions can be imposed to serve as deterrents to the general public. 
Protection orders are another enforcement mechanism that is available and currently being issued under the EMA, 2011. There is no jurisprudence specific to sustainable soil management yet. Under Section 104 of the EMA, 2011, the Director-General of ZEMA may, where considered necessary to conserve, protect and enhance the environment and natural resources in an area, serve a protection order on the owner, manager or person in control of the premises, vehicle, vessel, aircraft or equipment where the activity is occurring or will occur, or on any person who caused or permitted the activity. According to Section 104(2), a protection order may require the person on whom it is served to:

[t]ake any measures to avoid, remedy or mitigate any adverse effects and to (i) stop the activity that is resulting or is likely to result in, an adverse effect; (ii) control the activity; (iii) assess the actual or anticipated extent of the adverse effect; (iv) remedy any adverse effects caused by the activity; or (v) prevent a recurrence of the activity or the adverse effect.

Further, Section 104(3) requires that a person on whom a protection order is served complies with the requirements of the order by the date or dates specified in the order and if no date is specified, the person must comply with the order immediately. Contravention of this subsection is an offence, and the offender is liable, upon conviction, to a fine and imprisonment for a period not exceeding one year, or to both.

\subsection{Restoration orders}

Environmental restoration orders may be served on the owner, manager or person in control of the premises, vehicle, vessel, aircraft or equipment from which the discharge was or is being made; on any person who, at the time the discharge occurred, was the owner, manager or person in control of the premises, vehicle, vessel, aircraft or equipment from which the discharge was made; or on any person who caused or permitted the discharge. ${ }^{270}$ An environmental restoration order may require the person on whom it is served to take any measures that will assist in reducing or eliminating the risk or harm and to take any measures to:

(a) take such action as will prevent the continuation or cause of pollution; (b) restore land, including the replacement of soil, the replanting of trees and other flora and the restoration as far as may be, of outstanding geological, archaeological or historical features of the land or the area contiguous to the land or area as may be specified in the particular order; (c) take such action to prevent the commencement or continuation or cause of environmental hazard; (d) cease to take any action which is causing or may contribute to causing pollution or an environmental hazard; (e) remove or alleviate any injury to land or the environment or to the amenities of the area; (f) prevent damage to the land or the environment, aquifers beneath the land and flora and fauna in, on or under or about the land specified in the order or land or the environment contiguous to the

270 Section 105(1). 
land specified in the order; (g) remove any waste or refuse deposited on the land or sea specified in the order and dispose of the same in accordance with the provisions of the order

From the foregoing, environmental restoration orders may be instrumental in sustainable soil management, as seen in this provision which specifically identifies land restoration and soil replacement. However, it would be a challenge to enforce this provision owing to the requirement for scientific proof of degradation requiring restoration. In addition, the enforcement of this provision across the country would need skilled manpower, which the relevant institutions are lacking. At present, there is no jurisprudence on how this provision has been enforced. In like manner with other environmental orders, any person who contravenes these provisions commits an offence and is liable, upon conviction, to a fine or to imprisonment or to both.

\subsection{Compliance orders}

Section 106 empowers the ZEMA Director-General who may, when reasonable grounds exist that any condition of a licence issued under the EMA has been breached, to serve a compliance order on the licensee requiring the licensee to remedy the breach within the period stipulated in the order. A compliance order may require the suspension of the licence with immediate effect if necessary, to prevent or mitigate an imminent risk of significant adverse effects to the environment or to human health occurring; or may require the licensee to take specified measures to prevent or abate any adverse effect. These adverse effects may relate to soil as this provision is not specific to any aspect of the environment. Where a licensee fails to comply with a compliance order, ZEMA is empowered to take the necessary steps to remedy the breach and recover the cost from the licensee or vary the conditions of the licence; or revoke the whole licence. ${ }^{271}$ Failure to comply with a compliance order is an offence for which the offender may be fined or imprisoned, or both.

\subsection{Cost orders}

Where a person fails to comply with a requirement in an order, licence or approval issued under the EMA, 2011, ZEMA may issue a cost order requiring that person to reimburse ZEMA for the cost of taking the measures, as provided for under Section 107(1). A cost order is enforced as if it were an order of court if no application for the review of the cost order is made. ${ }^{272}$ 
Section 109 mandates any person to write to and request ZEMA to investigate an alleged contravention of the EMA. This requirement may not be possible for the illiterate and semi-literate, thus reducing accessibility. Such a written request must set out the reasons therefor, including the detailed factual grounds for believing that a contravention has occurred. Although the nature of the contravention in this section is not specific, it is arguable that it may relate to soil contamination or any other adverse occurrence that may be likely to compromise soil quality. The Director-General of ZEMA is mandated to consider the written request and, within 30 days, to decide whether or not to commence an investigation, and then accordingly notify the requesting person, in writing, of that decision, stating the reasons therefor, and, if applicable, the date upon which the Director-General intends to commence the investigation. ${ }^{273}$

In the event that the Director-General decides not to commence an investigation, the requesting person may lay a charge and initiate and conduct the prosecution on their own and may obtain the assistance of any other person in doing so. ${ }^{274}$ This is a very important provision as it gives leeway to private citizens to participate in ensuring that they have an environment that is clean and healthy. This provision can also be used to enhance soil protection. Where the charge is followed through in the courts of law:

The court shall not award any costs or damages against a person who initiates a prosecution after informing the Director-General in accordance with this section, unless the court finds that the primary motivation for the prosecution was not a concern for the public interest or for the enhancement, protection and conservation of the environment. ${ }^{275}$

While this section empowers private citizens to take part in environmental protection without fear of legal consequences such as costs, it also aims at ensuring that the progressive legal provisions are not abused by persons with frivolous, vexatious or malicious allegations. This provision is also important in advocating a culture of wholesome environmental well-being as it can readily accommodate causes of action in the interest of soil sustainability.

Section 110 empowers any person to sue for damages in respect of an act or omission that constitutes a contravention of the EMA or that is likely to have an adverse effect, whether or not that person or any other person has suffered, or is likely to suffer, any loss or harm from the act or omission. This right of action is in addition to any other legal rights or remedies available to a plaintiff or applicant. ${ }^{276}$ Further, Section 111 provides that a court that convicts a person of an offence under the EMA may, in addition to any other penalty imposed, order the person to take and pay for measures 
to avoid, remedy or mitigate any adverse effects arising from, or likely to arise from, the offence. These measures are also likely to be applicable in the preservation of soil quality.

The EMA makes provision for environmental crimes in Sections 117 and 119. The provisions of Section 117 relate to failure to undertake an EIA and these have been discussed in the section on EIAs. Section 119 provides that a person who:

(a) contravenes any environmental standards or guidelines established or prescribed under the EMA; (b) contravenes a measure prescribed or ordered under this Act; or (c) uses the environmental or natural resources in a wasteful or destructive manner contrary to the prescribed standards, measures or guidelines; commits an offence and is liable, upon conviction, to a fine not exceeding seven hundred thousand penalty units or to imprisonment for a period not exceeding seven years, or to both.

Although this provision does not specifically refer to any adverse effects on soil quality and quantity, it remains a possible solution in efforts to ameliorate the worsening challenge of soil degradation in Zambia. For example, in the agricultural sector, numerous non-legal interventions have been introduced to curb the widespread practice of 'slash and burn' or chitemene owing to its long-term negative impacts on the environment generally and soil sustainability specifically. In the event that some farmers remain averse to embracing the more sustainable farming practices being introduced, the provisions of Section 119 can be applicable for deterrence.

This section outlines some possible recommendations on addressing the challenges of soil sustainability legislation in Zambia. It has been noted that apart from some of the provisions of the EMA, there is presently no other legislation that can be used effectively to advance the soil cause in Zambia. Although the EMA contains progressive provisions that are relevant in the context of sustainable soil management, it has been observed that there are no provisions dedicated to soil as a natural resource. Most of the provisions of the EMA can be adapted to apply directly to soil with positive results. This analysis of soil-related legislation in Zambia has encountered some important lessons which need to be followed up.

There are positive and progressive provisions in the Constitution, EMA, 2011, mining legislation and other post-2010 sectoral legislation that need to be harnessed and coordinated into the country's soil legislation. It is remarkable that the National Climate Change Policy has been adopted and promises the enactment of climate-specific legislation in Zambia. This, together with prospects of new legislation in the agricultural and land sectors are opportunities to legislate in the interest of sustainable soil management in Zambia.

Control of foreign investors is required in order to ensure that land-use investments are sustainable and that the laws of the country are being observed. International 
cooperation and regional integration must be enhanced. For instance, the findings of international research entities must be implemented through regional cooperation. To illustrate, this report has shown that the recent IPCC Report findings (2019) connect climate change and land degradation, and ultimately soil health. It is important that such findings be tabled before regional meetings so that countries that are similarly affected are able to devise common and specific ways of implementation.

Political buy-in must be sought in all the different sectors, capitalising on the initiatives being spearheaded under the National Climate Change Policy (2016). There is a need to ensure political buy-in in environmental sustainability and natural resources issues, more particularly in soil sustainability as the 'cradle of ecosystem services'. This can be achieved through mechanisms of reducing institutional and system bureaucracy between local communities and the ultimate decisionmakers. Without effective community representation, citizen-power, and strong environmental NGOs to assist in ensuring checks and balances, effective environmental stewardship cannot be achieved. Ultimately, environmental and natural resources issues must be introduced on the agenda of political demands that political players in Zambia need to meet. Outdated legislation in the agricultural and land sectors, which are more directly aligned to soil conservation, is a major drawback, while the absence of a constitutional environmental right is a challenge that detracts from the positive provisions in the EMA, 2011.

The constitutional framework, sectoral and subsidiary legislation in Zambia have all been analysed with a view to pointing out how and whether soil sustainability matters are taken into consideration. It has been shown with absolute certainty that, while the Constitution and framework environmental legislation make provision for wholesome environmental well- being and define soil as an important constituent element of the environment, there are no clear and definite provisions on soil sustainability.

It is therefore recommended that, given the importance of soil to environmental well-being, there must be dedicated legislation cutting across all sectors. In the specific case of Zambia, it has been shown that the EMA has remarkable provisions in relation to other elements of the environment, such as water. In the same vein, there could either be a separate Act of Parliament outlining the importance of soil sustainability to all sectors of the economy or subsidiary legislation similar to the EIA and other regulations promulgated under the EMA. The content of the envisaged legislation could then be subjected to multiple stakeholders' input and approval. This could follow the usual process for the enactment of legislation.

The policy framework in the relevant sectors and cross-cutting issues have been evaluated. It has been noted that the policy framework refers to the main drivers of land/soil degradation but does not go further to prescribe mechanisms for addressing them in a more concerted manner. In the agricultural sector, for instance, there are ongoing initiatives to overhaul the entire legislative framework. This is an opportune time to ensure that interventions, such as conservation farming, are incentivised and 
that other unsustainable practices, such as the chitemene, are outlawed or discouraged with legal sanctions. In the Draft National Land Policy, it has also been noted that there are subtle provisions on how to encourage sustainable land use. This can be extended to soil conservation. In relation to land, and quite apart from tenure issues, it is possible to identify soil as an integral part that needs to be protected. This is another window of opportunity as the Lands Act (1995) has for some time been earmarked for overhaul.

Other more specific recommendations can be summarised as follows: There is no soil-specific legislation in Zambia. However, there are several provisions in many sectoral laws that can be used to ensure a sustainable soil regime. The Constitution, with its framework environmental legislation, has robust provisions for agriculture, mining, forestry and water resources. It is 'merely' the political will for enforcement that is still lacking.

Conservation farming could be a way of enhancing soil health. There is a need to identify and consolidate the numerous soil protection initiatives currently running in the agricultural sector into soil-specific legislation that will cut across all sectors. It is also important to enhance the establishment and coordination of a national soil information system covering various environmental issues pursuant to the EMA, 2011, while the Ministries of Agriculture and Lands and Natural Resources also operate others. Arising from this is the need for a centralised national institutional framework for sustainable soil management in Zambia.

Moreover, there is a need to infuse soil impact assessments in the various environmental assessments currently being implemented in the country. In relation to this, soil standards will need to be prescribed in relation to any developmental or other activities. Most farmers have already adopted sustainable farming practices that can be used to promote soil health. However, these initiatives are not coordinated.

In order to incentivise sustainable agricultural practices, sustainable soil mechanisms must be incorporated as a prerequisite for access to the Environment Fund established under the EMA, 2011, which makes provision for several innovative enforcement mechanisms, such as environmental audits and monitoring, restoration, protection, prevention, compliance and other orders, which are relevant for sustainable soil management. This prompts the need to survey ways of 'breathing life' into these provisions. Zambia still has very low awareness levels in relation to environmental issues in general which necessitates raising community awareness and educational activities on sustainable soil use to be introduced.

The agricultural, environment, land and mining sectors have research or monitoring units that generate a lot of data relevant to sustainable soil management. Furthermore, access to environmental information related to sustainable soil management is facilitated both by the Constitution and the EMA. There must be enhanced collaboration and cooperation as envisaged by the EMA in relation to all aspects of the environment. The creation and enforcement of a constitutional human rights paradigm for the environment is essential. The right to a clean, safe and healthy environment, the duty to 
conserve and protect the environment for the current and future generations, environmental procedural rights, climate justice and property rights would also assist with the inculcation of responsibility towards the environment and natural resources. In this light it is important to mention the threats to soil, which are both global and locally significant.

It is acknowledged that the law is but one of the myriad measures that can be employed to safeguard soil sustainability. Research has shown that approximately $20 \%$ of the world's land is degraded. ${ }^{277}$ It is imperative to recognise that land degradation is affecting almost all the world regions and could result in many human rights issues, specifically in sub-Saharan Africa, which has been identified as one of the hotspots of soil and land degradation. ${ }^{278}$ The negative effects which have a bearing on human rights compromise will affect a large portion of the world's poor population, resulting in a human rights crisis. On this score, it is essential to look at soil sustainability more holistically from different sectoral, disciplinary and geaographical perspectives.

\section{References}

Abdelghaffar, N., K. Bryant, C. Siang Bu, M. Campbell, B. Lewis, R. Low, K. Namit, D. Paredes, A. Silva \& C. Yu, 2016, Leveraging Chinese FDI for diversified growth in Zambia. Princeton University, Graduate School Policy Workshop, at https:/wws.princeton.edu/sites/default/files/content/Zambia\%20Final\%20Final\%20Report_27Apr2016.pdf, accessed 29 July 2019.

Addaney, M, E. Boshoff \& M. Gyan Nyarko, 2018, "Protection of environmental assets in urban Africa: Regional and sub-regional human rights and practical environmental protection mechanisms". Australian Journal of Human Rights $24 \quad$ (2), 182, at https://doi.org/10.1080/1323238X.2018.1480235, accessed 28 July 2019.

AFRODAD / African Forum and Network on Dept and Development, 2003, A critical analysis of the poverty reduction strategy papers: Processes and outcomes. The Case of Zambia, at https://bit.ly/3oX6gbs, accessed 16 January 2021.

AFRONET / Inter-African Network for Human Rights and Development, 1998, The dilemma of local courts in Zambia. A question of colonial legal continuity or deliberate customary law marginalisation? Lusaka: AFRONET.

Alori, E.T. \& C. Nwapi, 2014, “The international legal regime for sustainable soil”. In: Huks, R., T. Ako \& D. Olawuyi (eds), Food and agricultural law: Readings on sustainable agriculture and the law in Nigeria. Afebabalola University: Ado Ekiti, 98.

Ayub M.A., M. Usman, T. Faiz, M. Umair, M. Anwar ul Haq, M. Rizwan, S. Ali \& M. Zia ur Rehman, 2020, "Restoration of degraded soil for sustainable agriculture". In: Meena R.S. (ed.), Soil health restoration and management. Singapore: Springer, at https://doi.org/10.1007/978-981-13-85704_2, accessed 16 November 2019.

Blackwell, J.M., R.N. Goodwillie \& R. Webb, 1998, Environment and development in Africa. New York: World Bank, at https://doi.org/10.1596/0-8213-1608-7, accessed 5 February 2021.

278 See https://bit.ly/3pXI7CX; and https://bit.ly/3rutI1d, both accessed 3 February 2021. 
BoZ / Bank of Zambia, 2015, Foreign private investment and investor perceptions in Zambia: Rethinking, refocusing and implementing investment and export diversification strategies, at https://www.boz.zm/ForeignPrivateInvestmentReport2015.pdf, accessed 16 January 2021.

BoZ / Bank of Zambia, 2017a, Foreign private investment and investor perceptions in Zambia: Enhancing invest for export promotion and industrialisation towards inclusive growth, at https://www.boz.zm/report.pdf, accessed 30 June 2019.

BoZ / Bank of Zambia, 2017b, Bank of Zambia annual report. Lusaka: BOZ, at https://www.boz.zm/annual-reports.htm, accessed 30 June 2019.

Bull, M.M., 2014, "Reserved area: Barotseland of the 1964 agreement". Zambia Social Science Journal 5 (1), at http://scholarship.law.cornell.edu/zssj/vol5/iss1/4, accessed 15 January 2021.

Central Statistical Office, 2013, Population and demographic projections 2011-2035. Lusaka: Central Statistical Office.

Central Statistical Office, 2016, 2015 Living Conditions Monitoring Survey. Lusaka: Central Statistical Office.

Central Statistical Office, 2018, "Zambia in figures", at www.zamstats.gov.zm, accessed 20 August 2019.

Chapoto, A. \& B. Chisanga, 2016, Zambia agriculture status report 2016. Lusaka: Indaba Agricultural Policy Research Institute (IAPRI).

Chidumayo, E.N., 1987, “A shifting cultivation land use system under population pressure in Zambia”. Agroforest Systems 5, 15, at https://doi.org/10.1007/BF00046411, accessed 17 July 2019.

Chidumayo, E.N. \& D. Gumbo, 2013, "The environmental impacts of charcoal production in tropical ecosystems of the world: A synthesis". Energy for Sustainable Development 17 (2), 86, at https://doi.org/10.1016/j.esd.2012.07.004, accessed 15 January 2021.

Chileshe, A., 2001, Forestry outlook studies in Africa (FOSA) - Zambia. Rome: FAO.

Chinene, V.R.N., F. Maimbo, D.J. Banda, S.C. Msune, 1998, “A comparison of customary and leasehold tenure: Agriculture and development in Zambia". In: Groppo, P., Land reform, land settlement and cooperatives, 88, at http://www.fao.org/3/x1372t/x1372t07.htm, accessed 15 January 2021.

Christopolos, I., C. Aben, B. Bashaasha, H. Dhungana, E. Friis-Hansen, M. Funder, N. Thi Thanh Huong, D. Bahadur Khatri, L. Salloum Lindegaard, C. Mweemba, L. Duc Ngoan, I. Nyambe, H. Ojha, J. Okiror, A. Pain, L. Thi Hoa Sen, 2016, Understanding sub-national climate governance - Findings from Nepal, Uganda, Vietnam and Zambia. Copenhagen: DIIS, at https://pure.diis.dk/ws/files/614369/DIIS_RP_2016_5_WEB.pdf, accessed 5 February 2021.

Church, W.L., 1974, “The common law and Zambia”. Zambia Law Journal 6, 1.

Dupuy, K., P.T. Sambo, M. Funder \& E. Chama, 2019, Coordinating climate finance: Lessons from Zambia. PRIO Paper. Oslo: PRIO, at https://www.prio.org/utility/DownloadFile.ashx?id=1895\&type=publicationfile, accessed 5 November 2019.

Dymond, A., 2007, Undermining development? Copper mining in Zambia, at https://www.banktrack.org/download/undermining_development_copper_mining_in_zambia/underminingdevelopment.pdf, accessed 21 August 2019.

Engel, E., S. Rettberg, T. Rauch, S. Neubert, D. Richter, M. Minah \& C. Berg, 2017, Towards inclusive and sustainable rural transformation in Sub-sahara Africa. Berlin: Centre for Rural Development, at https://bit.ly/3txUGa1, accessed 9 May 2019.

Eriksen, C., 2007, "Why do they burn the 'bush'? Fire, rural livelihoods, and conservation in Zambia". The Geographical Journal 173 (3), 242.

Fadjukoff, P., 2015, "Promoting 21st Century literacy education in Zambia". In: Hölttä, S., A. Moore \& E. Pekkola (eds), Higher education institutions - partnering for development and change: 
Reflections of the first round of the Finnish HEI ICI Programme, 124, at https://bit.ly/3joVSIl, accessed 15 January 2021.

Geda, A. \& H. Kebret, 2008, "Regional economic integration in Africa: A review of problems and prospects with a case study of COMESA". Journal of African Economies 17 (3), 357, at https://doi.org/10.1093/jae/ejm021, accessed 15 January 2021.

Gilbey, B., J. Davies, G. Metternicht \& C. Magero, 2019, “Taking land degradation neutrality from concept to practice: Early Reflections on LDN target setting and planning”. Environmental Science and Policy 100, 230.

Gloppen, S., 2003, "The accountability function of the courts in Tanzania and Zambia”. Democratization 10 (4), 112.

Gumbo, D.J., M. Dumas-Johansen, G. Muir, F. Boerstler \& Z. Xia, 2018, Sustainable management of Miombo woodlands - Food security, nutrition and wood energy. Rome: Food and Agriculture Organization of the United Nations, at http://www.fao.org/3/i8852en/I8852EN.pdf, accessed 28 October 2019.

Hansjürgens, B., A. Lienkamp \& S. Möckel, 2018, "Justifying soil protection and sustainable soil management: Creation-ethical, legal and economic considerations". Sustainability 10 (10) 3807, at https://doi.org/10.3390/su10103807, accessed 20 August 2019.

Hinfelaar, M. \& J. Sichone, 2019, The challenge of sustaining a professional civil service amidst shifting political coalitions: The case of the Ministry of Finance in Zambia, 1991-2018. ESID Working Paper No. 122. Manchester: The University of Manchester, at www.effective-states.org, accessed 31 July 2019.

Huth, M.J., 1984, "The impact of rapid population growth, expanding urbanisation, and other factors on development in sub-saharan Africa: The contrasting responses of Tanzania and Kenya". International Journal of Sociology and Social Policy 4 (2), 1, at https://doi.org/10.1108/eb012963, accessed 1 May 2019.

Ige, R.A., 2015, "Legal pluralism in Africa: Challenges, conflicts and adaption in a global village". Journal of Law, Policy and Globalization 34, 59.

IMF / International Monetary Fund, 2005, Zambia: Enhanced initiative for heavily indebted poor countries. Country Report No. 05/137, Completion Point Document, at https://www.imf.org/external/pubs/ft/scr/2005/cr05137.pdf, accessed 15 January 2021.

IPCC / International Panel on Climate Change, 2019, Climate change and land. An IPCC special report on climate change, desertification, land degradation, sustainable land management, food security and greenhouse gas fluxes in terrestrial ecosystems, at https://www.ipcc.ch/srccl-reportdownload-page/, accessed 16 August 2019.

Japan Association for International Collaboration of Agriculture and Forestry, 2008, Agriculture and forestry in Zambia: Present situation and issues for development, at http://www.jaicaf.or.jp/publications/zanbia_agri.pdf, accessed 1 May 2019.

Kalaba, K.F., 2016, "Barriers to policy implementation and implications for Zambia's forest ecosystems". Forest Policy and Economics 69, 40.

Kibugi R., 2018, "Soil health, sustainable land management and land degradation in Africa: Legal options on the need for a specific African soil convention or protocol". In: Ginzky H., E. Dooley, I. Heuser, E. Kasimbazi, T. Markus \& T. Qin (eds), International yearbook of soil law and policy 2017. Cham: Springer, 387.

Kříbek B., V. Majer, P. Bezuško, J. Pašava, J. Adamovič, I. Nyambe, K. Liyungu \& F. Chibesakunda, 2006, "Impact assessment of mining and processing of copper and cobalt ores on the environment in the Copperbelt, Zambia". Geoscience Research Reports 40, 160, at http://www.geology.cz/zpravy/en/detail/2006-str-160-162, accessed 16 January 2021. 
Loenen, B., 1999, Land tenure in Zambia, at https://www.researchgate.net/publication/242672704_Land_tenure_in_Zambia, accessed 20 July 2019.

Mabey, N. \& R. McNally, 1999, Foreign investment and the environment: From pollution havens to sustainable development. London: WWF.

Madzudzo, E., A. Mulanda, J. Nagoli, J. Lunda, \& B.D. Ratner, 2013, A governance analysis of the Barotse floodplain system, Zambia: Identifying obstacles and opportunities. Penang: CGIAR Research Program on Aquatic Agricultural Systems.

Metternicht, G., M. Akhtar-Schuster \& V. Castillo, 2019, "Implementing land degradation neutrality: From policy challenges to policy opportunities for national sustainable development". Environmental Science and Policy 100, 189.

Mining Partnerships for Development, 2014, Enhancing mining's contribution to the Zambian economy and society, at https://miningforzambia.com/wp-content/uploads/2016/11/ICMM-Report-onMining-in-Zambia.pdf, accessed 10 May 2019.

Ministry of Agriculture and Cooperatives, 2004, First national agricultural policy 2004-2015. Lusaka: Ministry of Agriculture and Cooperatives.

Ministry of Agriculture, 2016, Second national agriculture policy 2016- 2020. Lusaka: Ministry of Agriculture.

Ministry of Chiefs and Traditional Affairs, 2016, Ministerial statement on increased membership of the House of Chiefs, at https://bit.ly/2Lu4fFP, accessed 15 January 2021.

Ministry of Energy, 2008, National energy policy. Lusaka: Ministry of Energy.

Ministry of Finance, 2011, Sixth national development plan. Lusaka: Ministry of Finance.

Ministry of Finance, 2017, Seventh national development plan. Lusaka: Ministry of Finance.

Ministry of General Education, 2017, Educational statistical bulletin, at https://bit.ly/3rt5gxl, accessed 15 January 2021.

Ministry of Lands and Natural Resources, 2017, National investment plan to reduce deforestation and forest degradation (2018-2022). Lusaka: Ministry of Lands and Natural Resources.

Ministry of Lands and Natural Resources, 2018, Ministerial statement on the outcome of the national validation meeting for the draft national land policy. Lusaka: Ministry of Lands and Natural Resources.

Ministry of National Development Planning, 2006, Vision 2030. Lusaka: Ministry of National Development Planning, at https://www.mndp.gov.zm/wp-content/uploads/2018/05/Vision-2030.pdf, accessed 15 January 2021.

Ministry of National Development Planning, 2016, National policy on climate change. Lusaka: Ministry of National Development Planning.

Ministry of National Development Planning, 2017, Seventh national development plan (2017-2021). Lusaka: Ministry of National Development Planning, at https://www.mndp.gov.zm/wp-content/uploads/2018/05/7NDP.pdf, accessed 3 February 2021.

Ministry of Tourism, Environment and Natural Resources, 2010, National climate change response strategy (NCCRS). Lusaka: Government of the Republic of Zambia, at https://www.adaptationundp.org/sites/default/files/downloads/zambia-climate_change_response_strategy.pdf, accessed 5 February 2021.

Ministry of Tourism and Arts, 2016, Tourism statistical digest 2015. Lusaka: Ministry of Tourism and Arts, at https://www.mota.gov.zm/?wpfb_dl=65, accessed 15 January 2021.

Monson, J., 2013, "Remembering work on the Tazara railway in Africa and China, 1965-2011: When "new men" grow old". African Studies Review 56 (1), 45, at https://doi:10.1017/asr.2013.5, accessed 15 January 2021. 
Mudenda, F.S., 2007, Land law in Zambia - cases and materials. Lusaka: University of Zambia Press.

Mudenda, M., 2010, Climate change and environmental threats, (Zambia): Climate change and urban slums in Lusaka, Zambia: Ignore, mitigate or adapt. FIG Congress, Facing the Challenges - Building the Capacity Sydney, Australia, 11-16 April 2010, at https://bit.ly/3cRDuX2, accessed 15 January 2021.

Mulenga, C., 2019, "Judicial mandate in safeguarding environmental rights from the adverse effects of mining activities in Zambia”. Potchefstroom Electronic Law Journal 22, at https://ssrn.com/abstract=3377116, accessed 10 July 2019.

Munalula, M.M., 2004, Legal process-cases, statutes and materials. Lusaka: University of Zambia Press.

Munyinda, N. \& L. Habasonda, 2013, Public participation in Zambia - The case of natural resources management. Copenhagen: Danish Institute for Human Rights, at https://menneskeret.dk/files/media/dokumenter/udgivelser/public_participation_study_final-nov2013.pdf, accessed 15 January 2021.

Mususa, P., 2012, "Mining, welfare and urbanisation: the wavering urban character of Zambia's Copperbelt". Journal of Contemporary African Studies 30 (4), 571.

Mvunga, M.P., 1978, Land law and policy in Zambia. Ph.D. thesis, London: University of London.

Mvunga, M.P., 1980, The colonial foundations of Zambia's land tenure system. Lusaka: National Educational Company of Zambia Limited (NECZAM).

Nalishebo, S., 2015, Lowering the repayment risk of Zambia's Eurobonds. Lusaka: ZIPAR, at http://www.zipar.org.zm/17-lowering-the-repay.ment-risk-of-zambia-s-eurobonds, accessed 15 January 2021.

Ndaba, S., 2015, The impact of foreign direct investment on economic growth in Zambia - A study in the context of a natural resource dependent economy. Research Paper presented in partial fulfilment of the requirements for obtaining the degree of Master of Arts in Development Studies, The Hague: Institute of Social Studies, at https://bit.ly/3s55co1, accessed 15 January 2021.

Ndulo, M. \& R.B. Kent, 1996, "Constitutionalism in Zambia: Past, present and future”. Journal of African Law 40 (2), 256.

Neubert, S., M. Kömm, A. Krumsiek, A. Schulte, N. \& L. Zeppenfeld Tatge, 2011, Agricultural development in a changing climate - Increasing resilience to climate change and economic shocks in crop production. Bonn: DIE, at https://www.files.ethz.ch/isn/128010/Studies\%2057.pdf, accessed 17 January 2021.

Orr, B.J., A.L. Cowie, V.M. Castillo Sanchez, P. Chasek, N.D. Crossman, A. Erlewein, G. Louwagie, M. Maron, G.I. Metternicht, S. Minelli, A.E. Tengberg, S. Walter \& S. Welton, 2017, Scientific conceptual framework for land degradation neutrality. A Report of the Science-Policy Interface, Bonn: United Nations Convention to Combat Desertification, at http://catalogue.unccd.int/814_LDN_CF_report_web-english.pdf, accessed 17 January 2021.

Osei-Hwedie B.Z., 1996, "Environmental protection and economic development in Zambia”. Journal of Social Development in Africa 11 (2), 57, at https://bit.ly/3cO3R08, accessed 18 January 2021.

OSISA / Open Society Initiative for Southern Africa, 2015, Effective delivery of public education services in Zambia. Lusaka: OSISA.

Phiri, B.J., 2006, A political history of Zambia. Trenton: Africa World Press, Inc.

Pimentel, D. \& N. Kounang, 1998, "Ecology of soil erosion in ecosystems". Ecosystems 1 (5), 416.

Plisnier, D.P., M. Nshombo, H. Mgana \& G. Ntakimazi, 2018, "Monitoring climate change and anthropogenic pressure at Lake Tanganyika". Journal of Great Lakes Research 44 (6), 1194, at https://doi.org/10.1016/j.jglr.2018.05.019, accessed 17 January 2021.

Pope Francis, 2015, Laudato Si. San Francisco: Ignatius Press. 
Prizzon, A., 2013, The age of choice: Zambia in the new aid landscape. London: Overseas Development Institute, at https:/www.odi.org/sites/odi.org.uk/files/odi-assets/publications-opinionfiles/9107.pdf, accessed 18 January 2021.

Republic of Zambia, 2009, The national policy on environment. Lusaka: Government of the Republic of Zambia, at https://www.oneplanetnetwork.org/sites/default/files/national_policy_on_environment_2009.pdf, accessed 2 February 2021.

Resilience and Economic Inclusion Team, 2016, Zambia climate action report. Dublin: Irish Aid, at https://www.irishaid.ie/media/irishaid/allwebsitemedia/30whatwedo/climatechange/ZambiaCountry-Climate-Action-Report-2016.pdf, accessed 18 January 2021.

Sambo, P.T., 2019, "The Environmental Management Act (2011): A basis for the growth of an environmental ethos and good environmental governance in Zambia?”. In: Kameri-Mbote, P., A. Paterson, O.C. Ruppel \& B.B. Orubebe (eds), Law | Environment | Africa. Baden-Baden: Nomos Publishers, 647.

Sambo, P.T., C. Haywood, D.A. Wardell, R. Kibugi \& M.-C. Cordonier Segger, 2015, Enabling legal frameworks for sustainable land-use investments in Zambia - Legal assessment report, at https://bit.ly/3rwFtV4, accessed 17 January 2021.

Sharma, N. \& R. Singhvi, 2017, "Effects of chemical fertilizers and pesticides on human health and environment: A review". International Journal of Agriculture, Environment and Biotechnology 10 (6), 675, at https://ndpublisher.in/admin/issues/IJAEBv10n6f.pdf, accessed 16 October 2019.

Shitumbanuma, V., P. Simfukwe, D. Kalala, B. Kaninga, B. Gondwe, M. Nambala, S. Kabwe, G. Siulemba, N. Kapulu, O. Lungu \& J. Mutegi, undated, Integrated soil fertility management in Zambia. Lusaka: The Soil Health Consortium, at https://bit.ly/3q46aQw, accessed 20 October 2019.

Sintayehu, D.W., 2018, "Impact of climate change on biodiversity and associated key ecosystem services in Africa: a systematic review". Ecosystem Health and Sustainability 4 (9), 225, at https://www.tandfonline.com/doi/full/10.1080/20964129.2018.1530054, accessed 15 January 2021.

Smith, P., 2018, "Managing the global land resource". Biological Sciences 285 (1874), at http://doi.org/10.1098/rspb.2017.2798, accessed 20 October 2019.

Stanchi, S., G. Falsone \& E. Bonifacio, 2015, "Soil aggregation, erodibility, and erosion rates in mountain soils (NW Alps, Italy)". Solid Earth 6, 403, at https://doi.org/10.5194/se-6-403, accessed 20 August 2019.

Stevens, C., 2019, "Reviving the right to development within the multilateral trade framework affecting (African) countries to actualize Agenda 2063". African Human Rights Law Journal 19 (1), 470, at https://dx.doi.org/10.17159/1996-2096/2019/v19n1a22, accessed 20 October 2019.

Stevens, C. \& N. Kanie, 2016, "The transformative potential of the Sustainable Development Goals (SDGs)". International Environmental Agreements: Politics, Law and Economics 16, 393, at https://doi.org/10.1007/s10784-016-9324-y, accessed 21 October 2019.

Sunlu U., 2003, “Environmental impacts of tourism”. In: Camarda D. \& L. Grassini (eds), Local resources and global trades: Environments and agriculture in the Mediterranean region. Bari: CIHEAM, 263, at http://om.ciheam.org/om/pdf/a57/04001977.pdf, accessed 31 October 2019.

Tembo, T., 2016, "Protect environment from chemical fertilizers". Zambia Daily Mail, 2 May 2016.

The Commonwealth, 2019, "Zambia - Constitution and politics", at http://thecommonwealth.org/ourmember-countries/zambia/constitution-politics, accessed 15 April 2019.

U1 Zaman, M., S. Bhat, S. Sharma \& O. Bhat, 2018, "Methods to control soil erosion - A review". International Journal of Pure and Applied Bioscience 6 (2), 1114, at http://dx.doi.org/10.18782/2320-7051.6462, accessed 18 January 2021. 
UNCTAD / United Nations Conference on Trade and Development, 2017, Promoting foreign investment in the Sustainable Development Goals (SDGs). Geneva: UNCTAD, at https://unctad.org/system/files/official-document/diaepcb2018d4_en.pdf, accessed 18 January 2021.

UNEP / United Nations Environment Programme, 2015, Benefits of forests ecosystems in Zambia and the role of REDD + in a green economy transformation. Nairobi: UNEP, at https://bit.ly/3quTbaR, accessed 18 January 2021.

United States Agency for International Development, 2010, Zambia: Land tenure and property rights profile, at http://www.usaidlandtenure.net/sites/default/files/country-profiles/full-reports/USAID_Land_Tenure_Zambia_Profile.pdf, accessed 3 February 2021.

United States Department of State, 2015, Zambia investment climate statement, at http://www.state.gov/documents/organization/242010.pdf

van Tine, R., 2017, "Reflections, analysis, and significance for human ecology of Pope Francis's encyclical letter 'Laudato Si': On care for our common home”. Human Ecology Review 23 (1), 141.

Von Malitz, G., J. Gambiza, K. Kellner, T. Rambau, L. Lindeque \& B. Kgope. 2019, "Experiences from South African land degradation neutrality target setting process". Environmental Science and Policy 101, 54.

World Bank, 2015, "Doing business 2016: Economy profile 2016 - Zambia”, at https://bit.ly/37oj5Fz, accessed 15 February 2021.

World Bank, 2016, Land governance assessment - Zambia. Country Report, Lusaka: World Bank.

Young, A., 1989, Agroforestry for soil conservation. Wallingford: International Council for Research in Agroforestry, at http://old.worldagroforestry.org/downloads/Publications/PDFS/03_Agroforestry_for_soil_conservation.pdf, accessed 11 October 2019.

ZDA / Zambia Development Agency, 2017, Zambia's investor guide handbook, at http://impactcapafrica.com/resources/pdf/Investor\%20Guide\%20Handbook\%20-\%20Apri12017.pdf.

ZEMA / Zambia Environmental Management Agency, 2017, Zambia environment outlook report, at http://www.zema.org.zm/index.php/download/zambia-environment-outlook-report-3/, accessed 11 October 2019.

Zongwe, D.P., 2011, An introduction to the law of the Southern African Development Community. New York: Hauser Global Law School Programme, at https:/www.nyulawglobal.org/globalex/Southern_African_Development_Community.html, accessed 18 January 2021. 
